\title{
Viticultural wood waste as a source of polyphenols of interest: opportunities and perspectives through conventional and emerging extraction methods
}

\author{
Marion Zwingelstein ${ }^{a, b}$, Micheline Draye $^{a}$, Jean-Luc Besombes ${ }^{a}$, Christine Piot ${ }^{a}$ and Gregory \\ Chatel $^{a^{*}}$ \\ $a_{\text {Univ. Savoie Mont Blanc, LCME, F-73000 Chambéry, France. }}$ \\ ${ }^{b}$ Agence de l'Environnement et de Maîtrise de l'Energie (ADEME), F-49004, Angers, France
}

\begin{abstract}
Viticultural waste has been widely demonstrated to contain high-added value compounds named the stilbenes. Among them, trans-resveratrol (Rsv) and trans- $\varepsilon-$ viniferin (Vf) are the most abundant in particular in grape canes. Various emerging methods such as ultrasound-assisted extraction (UAE), microwave-assisted extraction (MAE) or pressurized solvent extraction (PSE) have been studied to recover Rsv and Vf from grape canes in order to enhance their extraction. This paper gives a critical overview of the techniques used to this end, integrating conventional and nonconventional methods investigated in the literature as well as those used in industrial processes. It finally highlights that the unconventional technics are usually less timeconsuming than conventional extraction ones but further investigations for the discussed compounds and biomass are needed to optimize and understand the influence of the individual parameters of each extraction process.
\end{abstract}

Keywords: Grape canes; stilbenes; extraction efficiency; trans-resveratrol; trans- $\varepsilon$ viniferin 


\section{Introduction}

The phenomenon of global warming and its consequences are attracting a lot of attention lately, not only within the scientific community but also among the general public. Thus, the last years have seen emerged new habits in the consumer society to minimize its environmental impact including a growing demand for natural and biobased products (French Environment and Energy Management Agency (ADEME), 2019). Valorization of renewable resources, especially agricultural biomass, is of great interest for this purpose because of its richness in high added value compounds and its abundance (Abosede et al., 2017). In addition, countries are attached to their culture and heritage on which their economy could be based. For example, in 2017, France was still the first exporter and the second largest producer of wine worldwide with a production of 36.7 million hectoliters and a vineyard surface of 787,000 hectares (International Organization of Vine and Wine, 2019). Furthermore, these agricultural surfaces also represent huge amounts of biomass generated during the winter pruning of vineyards with about 1.8 million tons of grape canes and grapevine stocks wasted each year (FranceAgriMer, 2019). Indeed, winegrowers usually select one or two grape canes that will remain on the grapevine plant (Figure 1) to give vigor to the grapes for the new season. This implies that they get rid of the rest of grapes canes. However, these residues have attracted a lot of attention during the last decade since they are known to contain high added value molecules, such as stilbenes (Lambert et al., 2013). Transresveratrol is the first brick of these secondary metabolites. Deriving from the shikimicpolymalonic acid pathway the compound is biosynthesized by the combination of three 
malonyl CoA and one p-coumaroyl-CoA by stilbene synthase (StSy) (RoubelakisAngelakis, 2001; Rivière et al., 2012). Stilbenes act as phytoalexins in grapevine plants, which means that they protect them against aggressions from pathogenic microorganisms (Rivière et al., 2012).

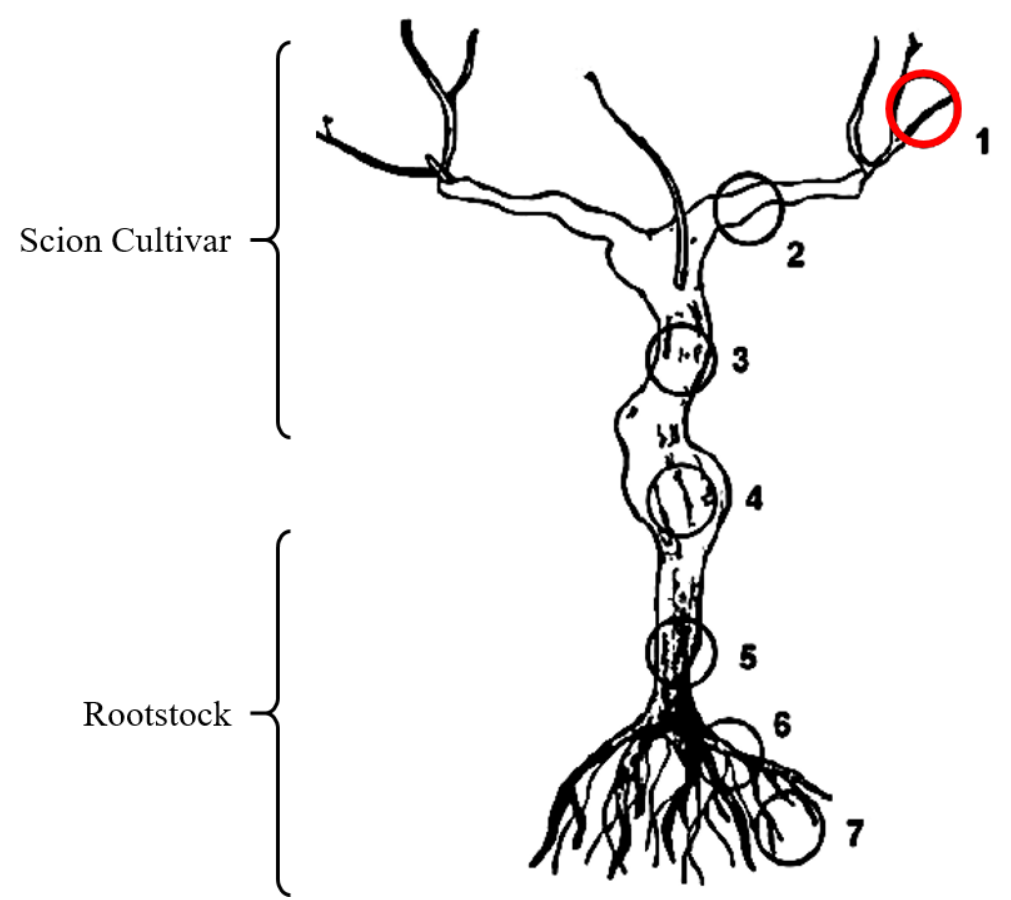

Figure 1. Parts of a grapevine plant. 1) grape cane, 2) arm, 3) upper trunk, 4) grafting zone, 5) lower trunk, 6) roots, 7) rootlets. Figure and nomenclature are adapted from Gabaston et al. (2019).

Especially, trans-resveratrol and its dimer trans- $\varepsilon$-viniferin (Figure 2) used in extracts enriched in polyphenols (as a cocktail) or as pure compound have a wide range of 
applications. They present various benefits, especially in human health showing anticarcinogenic, cardioprotective and antioxidant properties (Billard et al., 2002; Baur et al., 2006; Romain et al., 2012). They could also be used as antifungal or as preservatives in wine (Schnee et al., 2013; Raposo et al., 2016). Trans-resveratrol (Rsv) is usually obtained by extracting roots of Japanese knotweed roots (Fallopia Japonica), skin and berries of grapes or by chemical synthesis whereas trans-e-viniferin (Vf) is currently synthesized from Rsv (Farina et al., 2006; Singh et al., 2015; Chen et al., 2016; Lindgren et al., 2016). Biotechnologies such as cells culture and enzymatic fermentation are also promising tools to provide these compounds (Chastang, 2014; Li et al., 2015; Tisserant et al., 2016). Other secondary metabolites such as flavonoids (catechin and epicatechin) and compounds released from lignin degradation (especially phenolic acids) are also found in grape canes (Çetin et al., 2011; Lambert et al., 2013; Sánchez-Gómez et al., 2014). Since large amounts of vine plant material potentially rich in stilbenes remain unvalued (generally burned on the field or composted), a growing interest in extracting trans-resveratrol and trans- $\varepsilon$-viniferin from grape canes has

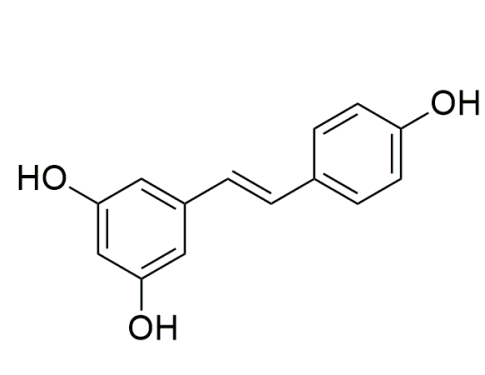

1

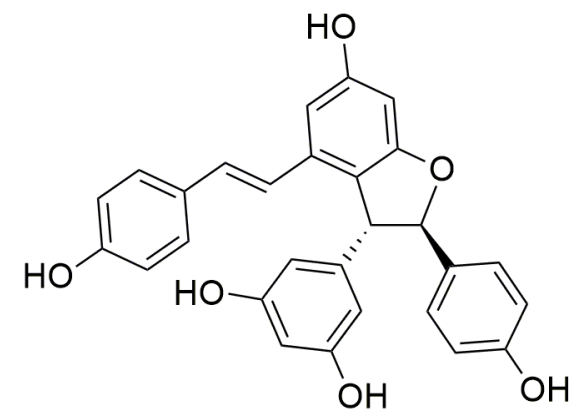

2

Figure 2. Chemical structures of trans-resveratrol (1) and its dimer trans-e-viniferin (2). 
emerged in recent years. This review article proposes an inventory and a comparison of conventional and emerging extracting methods based on their efficiency for extracting both compounds. Then, other parameters independent of extraction steps that could also influence the recovery of the targeted stilbenes are discussed.

\section{Conventional methods: a base of comparison}

By conventional methods or conventional solid-liquid extraction (CSLE) is understood any process requiring simple maceration in a solvent with or without stirring and at temperatures between room temperature (rt) and reflux. This category also includes Soxhlet extraction. In this part, the main parameters that impact the extraction efficiency of conventional methods will be discussed by comparing different studies to highlight the advantages and disadvantages of the technic. The yields of extraction are expressed as milligrams of trans-resveratrol and trans-e-viniferin per kilograms of grape canes, $\mathrm{mg}_{(\mathrm{Rsv})} \cdot \mathrm{kg}^{-1}$ and $\mathrm{mg}(\mathrm{Vf}) \cdot \mathrm{kg}^{-1}$ respectively.

\subsection{Extraction solvents}

In 2008, the work of Rayne et al. (2008) was one of the first to propose the valorization of Pinot Noir grape canes as a source of trans-resveratrol (Rsv) and trans- $\varepsilon$-viniferin (Vf) using diverse solvents with different dielectric constants. Liquid chromatography analyses with diode array detection of their global extracts showed that the highest yields for both molecules were obtained in $30 \mathrm{~min}$ at room temperature using ethanol/water 80:20 (v/v) with $3450 \mathrm{mg}_{(\mathrm{Rsv})} \cdot \mathrm{kg}^{-1}$ and $1300 \mathrm{mg}_{(\mathrm{Vf})} \cdot \mathrm{kg}^{-1}$ (Table 1, Entry 6). Authors explain the efficiency of the hydro-alcoholic mixtures by their polarity $(36<\varepsilon$ 
$<42$ ) and their ability to form hydrogen bond with phenolic compounds. According to the values reported by Robinson et al. (2015), Rsv solubility in alcohol could reach $87.98 \mathrm{mg} \cdot \mathrm{mL}^{-1}$ but without stating clearly which alcohol they used. With dielectric constants in the same range and also a hydrogen bonding ability, dimethylformamide and dimethylsufoxide/acetone 54:46 (v/v) give similar results. Other studies also report the use of acetone (Table 1, Entries 2 and 4) allowing relatively good yields of extraction $\left(>1500 \mathrm{mg}_{(\mathrm{Rsv})} \cdot \mathrm{kg}^{-1}\right.$ and $\left.>2800 \mathrm{mg}_{(\mathrm{Vf})} \cdot \mathrm{kg}^{-1}\right)$ (Lambert et al., 2013; Guerrero et al., 2016). However, hydro-alcoholic mixtures are usually preferred because they are non-toxic and low-cost.

In the same worry of sustainability, Rodríguez-Cabo et al. (2018) conducted an investigation on the feasibility of using alcoholic distillates. These distillates are obtained from waste generated during wine elaboration and present ethanol contents in the range of $40-45 \%$. They show excellent Rsv and Vf extraction capacities (2181 $\mathrm{mg}_{(\mathrm{Rsv})} \cdot \mathrm{kg}^{-1}$ and $2650 \mathrm{mg}(\mathrm{Vf}) \cdot \mathrm{kg}^{-1}$ ) when compared to a classical mixture ethanol/water 50:50 (v/v) in a Soxhlet extraction (Table 1, Entry 14). Despite their apparent effectiveness, the use of alcoholic distillates does not surely make the process ecofriendlier as stated by authors. Indeed, these liquids cannot be defined as a waste to reuse (Directive 2008/98/CE of the European Parliament and of the Council, 2008) since they are intentionally produced and are considered as an external output (Directive 2010/75/EU of the European Parliament and of the Council, 2010). Nevertheless, according to data shown in Table 1, ethanol/waster mixtures seem to be the preferred solvent to extract trans-resveratrol and trans- $\varepsilon$-viniferin. 


\subsection{Solvent-to-solid ratio}

According to the mass transfer principles, an increase of the solvent-to-solid ratio (also called sometimes hydromodule) improves the diffusion rate in a solid-liquid extraction (Cacace and Mazza, 2003). Pinelo et al. (2005) demonstrated that an increase of this ratio (expressed in milliters of solvent per gram of solid, $\mathrm{mL} \cdot \mathrm{g}^{-1}$ ) from 1 to $5 \mathrm{~mL} \cdot \mathrm{g}^{-1}$ could dramatically improve the extraction of phenolic compounds from grape pomace. Angelov et al. (2016) also approved this low limit of $5 \mathrm{~mL} \cdot \mathrm{g}^{-1}$ as it is accurate for good wetting of grapevine stems and to extract total phenolic content (TPC expressed in milligrams of gallic acid equivalents per gram of grape canes, $\left.\mathrm{mg}_{(\mathrm{GAE})} \cdot \mathrm{g}^{-1}\right)$. The authors also studied TPC extraction from globe artichoke and rosehip while increasing solventto-solid ratio (Angelov et al., 2014, 2015). The obtained results indicate that variation from 5 to $10 \mathrm{~mL} \cdot \mathrm{g}^{-1}$ involves better TPC extraction (from 25.6 to $35.1 \mathrm{mg}_{(\mathrm{GAE})} \cdot \mathrm{g}^{-1}$ for rosehip and from 6 to $9 \mathrm{mg}_{(\mathrm{GAE})} \cdot \mathrm{g}^{-1}$ for globe artichoke) with then no improvement of TPC levels from 10 to $20 \mathrm{~mL} \cdot \mathrm{g}^{-1}$. Concerning the high limit of the solvent-to-solid ratio, Karacabey and Mazza (2008) demonstrated thanks to experimental design plan that a ratio in the range of 36.8 to $103.6 \mathrm{~mL} \cdot \mathrm{g}^{-1}$ has no significant impact on the extraction efficiency of Rsv and Vf from Pinot Noir grape canes. However, the authors did not study a lower value. According to Table 1, Entries 1-15, most of the conventional extractions of Rsv and Vf from grape canes use a solvent-to-solid ratio in the range of 5$50 \mathrm{~mL} \cdot \mathrm{g}^{-1}$. In summary, it seems there is an optimal solvent-to-solid ratio comprised between approximately $5 \mathrm{~mL} \cdot \mathrm{g}^{-1}$ and $40 \mathrm{~mL} \cdot \mathrm{g}^{-1}$ and apparently near from $10 \mathrm{~mL} \cdot \mathrm{g}^{-1}$ according to data available in the literature. However, further investigations are needed 
to find the accurate limit to render the extraction process economically and environmentally viable but also to make the extraction as efficient as possible in the case of Rsv and Vf recovery from grape canes. Indeed, it seems there is no study that gives a precise value in this specific case and it could depend on the raw material and the compounds studied.

\subsection{Extraction temperature}

There are few studies published in the literature on the impact of temperatures variations on the Rsv, Vf and other stilbenes extraction from grape canes using a conventional method (Rajha et al., 2015b; Soural et al., 2015). Using CSLE of grape pomace, grape skin berries and grape canes, temperature increase from $20{ }^{\circ} \mathrm{C}$ to $80{ }^{\circ} \mathrm{C}$ presents a positive effect on Rsv and Vf extraction and no degradation of both compounds occurs (Romero-Pérez et al., 2001; Karacabey and Mazza, 2008; Planinić et al., 2015). Ethanol/water mixtures usually employed do not afford to use higher temperatures in a conventional system because of their boiling points around $80{ }^{\circ} \mathrm{C}$. Another study shows that Rsv kept in aqueous solutions at $25{ }^{\circ} \mathrm{C}$ and $37{ }^{\circ} \mathrm{C}$ is completely degraded in only 10 days (Zupančič et al., 2015). To go deeper in the analysis of temperature effect, it is necessary to take into account some studies using non-conventional extraction processes. Indeed, it is known that trans-resveratrol and trans- $\varepsilon$-viniferin are easily degraded at higher temperatures than $105{ }^{\circ} \mathrm{C}$ and $140{ }^{\circ} \mathrm{C}$ respectively under 5.2 MPa pressurized extraction (Karacabey et al., 2012) and higher than $100{ }^{\circ} \mathrm{C}$ under $10 \mathrm{MPa}$ (Zachová et al., 2019). However, the works of Piñeiro et al. 
(2013) mention that temperatures higher than $75^{\circ} \mathrm{C}$ can cause Rsv and Vf levels decrease when ultrasound irradiation is used on grape stems whereas it is not the case for total stilbenes extraction from grape canes (Piñeiro et al., 2016). On another hand, microwaves apparently favor high temperatures since at $100{ }^{\circ} \mathrm{C}$ almost no degradation of compounds occurs (Liazid et al., 2007; Piñeiro et al., 2017).

To summarize, the accurate temperatures range could be then dependent on the extraction method and the raw material used. Whatever is the exact limit, the type of solvent used in CSLE (mixture of alcohols, water and acetone) determines the temperatures range as shown in Table 1, Entries 1-15.

\subsection{Extraction time}

Then, extraction duration also represents an important factor that could drastically alter the extraction efficiency. Luque-Rodriguez et al. (2006) studied the extraction kinetics of TPC from grape canes. They demonstrated that TPC level increases from 4 to 7 $\mathrm{mg}_{(\mathrm{GAE})} \cdot \mathrm{g}^{-1}$ between 1 and $20 \mathrm{~h}$ of conventional solid-liquid extraction and then reaches a plateau (Figure 3 A). The same tendency is described by the work of Rajha et al. (2015b) with $2.6 \mathrm{mg}_{(\mathrm{GAE})} \cdot \mathrm{g}^{-1}$ for $30 \mathrm{~min}$ of extraction in ethanol/water 50:50 (v/v) at $66.6^{\circ} \mathrm{C}$ and more than $8 \mathrm{mg}(\mathrm{GAE}) \cdot \mathrm{g}^{-1}$ for $3 \mathrm{~h}$. However, caution is required when results are expressed as TPC. Indeed, its increase does not necessarily induce an increase in stilbenes content (Moreira et al., 2018). Soural et al. (2015) worked particularly on Rsv and Vf extraction from Cabernet Moravia grape canes. They pointed out a clear fivefold increase of their (Zupančič et al., 2015). These durations are used industrially 

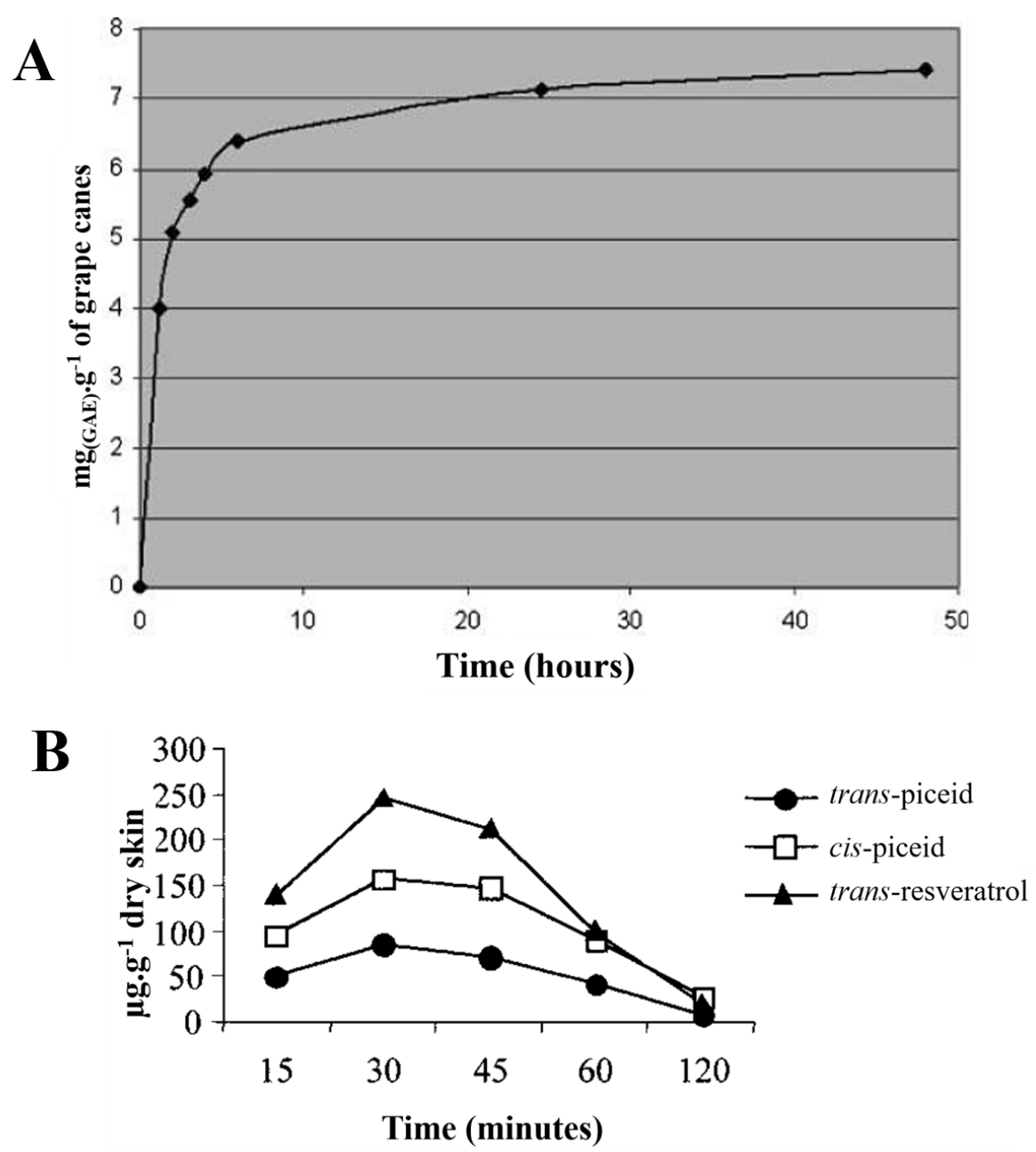

Figure 3. Impact of conventional solid-liquid extraction (ethanol/water 80:20 (v/v)) duration on A) TPC recovery from grape canes according to the method of LuqueRodríguez et al. (2006) (15 mL.g $\mathrm{g}^{-1}$, room temperature) and B) stilbenes contents in grape berry skins according to the method of Romero-Pérez et al. (2001) (125 mL.g-1, $\left.60^{\circ} \mathrm{C}\right)$. The figures are adapted from the mentioned publications.

levels in extracts between $8 \mathrm{~h}$ and 4 days of maceration in acetone at room temperature with then a slight decrease at 7 days probably due to their degradation or isomerization 
(Table 1, Entries 11 and 12). On the other hand, Romero-Pérez et al. (2001) worked on the Rsv recovery from grape berry skins and showed that more than 30 min of extraction in ethanol/water 80:20 (v/v) involved a loss of the compound at $60{ }^{\circ} \mathrm{C}$ (Figure $3 \mathrm{~B}$ ). Undoubtedly, extraction duration is determined by the solvent and the temperature chosen as noticed by Pinelo et al. (2005) and to the matrix extracted. There is a lack of data on these interactions for the discussed applications.

\section{5. $p H$ and light effects on extraction processes}

$\mathrm{pH}$ variations have a clear effect on Rsv stability. From low $\mathrm{pH}$ values until neutrality the compound is stable for several days but it rapidly degrades at $\mathrm{pH}$ values superior to 7 (Robinson et al., 2015; Zupančič et al., 2015). Indeed, in alkaline conditions, Rsv is deprotonated and polymerizes (Francioso et al., 2014). Trela and Waterhouse (1996) also described a decrease of Rsv stability at pH 10 (half-life of $1.6 \mathrm{~h}$ ) whereas at $\mathrm{pH}$ 1-7 it is stable for at least 28 days. This could partly explain the low Rsv levels of Rajha et al. (2014) who used $\mathrm{NaOH}$ to enhance polyphenols extraction from Grenache Blanc grape canes (Table 1, Entry 19). Nevertheless, no clear data was found for Vf stability under $\mathrm{pH}$ variations. However, at $\mathrm{pH}$ of 7.4 and a temperature of $23{ }^{\circ} \mathrm{C}$ Vf degrades slowly when compared to Rsv suggesting that dimerization stabilizes the compound (Willenberg et al., 2012). In the same conditions, both compounds are degraded in only $4 \mathrm{~h}$ under room light exposure. Indeed, Rsv is known to be highly sensitive to light exposure, especially under UV irradiations or sunlight and undergoes an isomerization in cis-resveratrol (Camont et al., 2009; Silva et al., 2013; Zupančič et al., 2015). 
Besides, it seems that UV-Vis spectrum isomerizes faster Rsv than UV or Vis spectrum alone demanding a special care to limit the extraction exposure from direct sunlight. Less studied, Vf seems to be less sensitive to light than Rsv but it is also subjected to isomerization in $c i s-\varepsilon$-viniferin under light exposure (Courtois et al., 2019).

\subsection{Some drawbacks to solve}

Studying and improving extraction efficiency at the laboratory scale is the first step in setting up an industrial process to value grape canes as a source of trans-resveratrol and trans- $\varepsilon$-viniferin. According to all the findings mentioned above and as seen in Table 1, Entries 1-15, hydro-alcoholic mixtures (specially ethanol/water mixtures) and medium temperatures (from room temperature to $100^{\circ} \mathrm{C}$ ) are since widely used in laboratory works to obtain both molecules from grape canes but also in industrial processes as seen in Table 1, Entries 11 and 12. These solvents are usually considered as environmentally preferable solvents and the use of low and medium temperatures limits the energy consumption (Capello et al., 2007). According to these aspects it could be assumed that CSLE is an eco-friendly way to conduct extraction experiments. However, it is considered as time- and solvent-consuming with duration in patents up to $20 \mathrm{~h}$ of extraction, solvent-to-solid ratios up to $8 \mathrm{~mL} \cdot \mathrm{g}^{-1}$ and numerous consecutive extractions (Izard and Fourneron, 2001; Vercauteren and Salmi, 2012). Moreover, yields expressed in Table 1 are measured in crude extracts without any purification. Extracts enriched in Rsv and Vf as performed in patents require supplementary purification steps causing losses (discussed in "What about the purification?" section below). The question of 
consecutive extractions necessity has also to be considered. Rayne et al. (2008) got acceptable yields with low solvent-to-solid ratio and temperature and short extraction duration by repeating extraction three times (Table 1, Entry 6). Despite its simplicity, inexpensiveness and then its recurrence in industries, the use of CSLE is questionable on environmental aspects especially concerning the large amount of solvent used (European Council directive 2010/75/EU, 2010; Zuin and Ramin, 2018). Furthermore, it also requires additional concentration/purification steps and intensive heating and/or mixing (Rombaut et al., 2014). Consequently, the scientific community working on the subject tried to develop emerging techniques to bring a solution to the main drawbacks of conventional method.

Table 1. Summary table of non-exhaustive published works on Rsv and Vf extraction from grape canes according to the technique used (CSLE: conventional solid-liquid extraction, MAE: microwave assisted extraction, UAE: ultrasound assisted extraction, PSE: pressurized solvent extraction, rt: room temperature, rpm: rotation per minute)

\begin{tabular}{|c|c|c|c|c|c|c|c|}
\hline Entry & Method & $\begin{array}{l}\text { Grape canes } \\
\text { variety }\end{array}$ & Initial conditions & $\begin{array}{l}\text { Experimental } \\
\text { conditions }\end{array}$ & \multicolumn{2}{|c|}{ Yields $\left(m g . \mathrm{kg}^{-1}\right)$} & Ref. \\
\hline 1 & CSLE & Horoz karasi & $\begin{array}{l}\text { Dried ( } 40^{\circ} \mathrm{C} \text { in oven) } \\
\text { until constant weight, } \\
\text { powdered }<1 \mathrm{~mm}\end{array}$ & $\begin{array}{l}\text { Ethanol/water } 60: 40 \\
(\mathrm{v} / \mathrm{v}) 20 \mathrm{~mL} \cdot \mathrm{g}^{-1}, 30 \\
\text { min, } 80^{\circ} \mathrm{C} \text {, stirring }\end{array}$ & 0.0394 & - & $\begin{array}{l}\text { Çetin et al. } \\
(2011)\end{array}$ \\
\hline 2 & CSLE & Gewurztraminer & $\begin{array}{l}\text { Choped to smaller } \\
\text { pieces and dried ( } 40 \\
{ }^{\circ} \mathrm{C} \text { ) until constant } \\
\text { weight, powdered }\end{array}$ & $\begin{array}{l}\text { Acetone/water 60:40 } \\
(\mathrm{v} / \mathrm{v}) 50 \mathrm{~mL} \cdot \mathrm{g}^{-1} \\
\text { overnight, } \mathrm{rt}\end{array}$ & 317 & 2810.44 & $\begin{array}{l}\text { Guerrero et } \\
\text { al. (2016) }\end{array}$ \\
\hline 3 & CSLE & Cabernet Franc & $\begin{array}{l}\text { Cut in } 10 \mathrm{~cm} \text { long } \\
\text { sections and stored at } \\
20^{\circ} \mathrm{C} \text { for } 10 \text { weeks, } \\
\text { powdered }<1 \mathrm{~mm} \text { and } \\
\text { freeze-dried }\end{array}$ & $\begin{array}{l}\text { Ethanol/water } 60: 40 \\
(\mathrm{v} / \mathrm{v}) 20 \mathrm{~mL} \cdot \mathrm{g}^{-1}, \\
30 \mathrm{~min}, 83^{\circ} \mathrm{C}, 1400 \\
\mathrm{rpm}\end{array}$ & 6384 & - & $\begin{array}{l}\text { Houillé et al. } \\
\text { (2015a) }\end{array}$ \\
\hline
\end{tabular}




\begin{tabular}{|c|c|c|c|c|c|c|c|}
\hline 4 & CSLE & Pinot Noir & $\begin{array}{l}\text { Cut into pieces } \\
\text { Dried }\left(40^{\circ} \mathrm{C}\right) \text { for } 5 \\
\text { days, powdered }<0.75 \\
\mu \mathrm{m}\end{array}$ & $\begin{array}{l}\text { Acetone/water 60:40 } \\
(\mathrm{v} / \mathrm{v}) 50 \mathrm{~mL} \cdot \mathrm{g}^{-1}, \\
\text { overnight, } \mathrm{rt}\end{array}$ & 1526 & 3737 & $\begin{array}{l}\text { Lambert et } \\
\text { al. (2013) }\end{array}$ \\
\hline 5 & CSLE & Tinta Roriz & $\begin{array}{l}\text { Dried }\left(50{ }^{\circ} \mathrm{C} \text { in oven }\right) \\
\text { for } 24 \mathrm{~h} \text {, powdered }<1 \\
\mathrm{~mm}\end{array}$ & $\begin{array}{l}\text { Ethanol/water } 50: 50 \\
(\mathrm{v} / \mathrm{v}) 40 \mathrm{~mL} \cdot \mathrm{g}^{-1} \\
2 \mathrm{~h}, 55^{\circ} \mathrm{C}, 100 \mathrm{rpm}\end{array}$ & 1330 & - & $\begin{array}{l}\text { Moreira et } \\
\text { al. }(2018)\end{array}$ \\
\hline 6 & CSLE & Pinot Noir & $\begin{array}{l}\text { Dried }\left(45^{\circ} \mathrm{C}\right) \text { for } 48 \\
\mathrm{~h} \text {, powdered }<1 \mathrm{~mm}\end{array}$ & $\begin{array}{l}\text { Ethanol/water } 70: 30 \\
(\mathrm{v} / \mathrm{v}) 8 \mathrm{~mL} \cdot \mathrm{g}^{-1} \\
30 \mathrm{~min}, \mathrm{rt} \text { ( } 3 \text { times })\end{array}$ & 3450 & 1300 & $\begin{array}{l}\text { Rayne et al. } \\
(2008)\end{array}$ \\
\hline 7 & CSLE & Airen & $\begin{array}{l}\text { Dried (rt) for } 72 \mathrm{~h} \\
\text { until final humidity } \\
6.5 \%\left(\mathrm{~g}_{\text {water }} / 100 \mathrm{~g}_{\text {of }}\right. \\
\text { sample }) \text {, powdered < } \\
0.42 \mathrm{~mm}\end{array}$ & $\begin{array}{l}\text { Water } 5 \mathrm{~mL} \cdot \mathrm{g}^{-1}, 60 \\
\min , 100{ }^{\circ} \mathrm{C}\end{array}$ & 29 & - & $\begin{array}{l}\text { Sánchez- } \\
\text { Gómez et al. } \\
(2014)\end{array}$ \\
\hline 8 & CSLE & Pinot Noir & $\begin{array}{l}\text { Freeze-dried, } \\
\text { powdered } \sim 0.26 \mathrm{~mm}\end{array}$ & $\begin{array}{l}\text { Ethanol/water } 80: 20 \\
(\mathrm{v} / \mathrm{v}) 125 \mathrm{~mL} \cdot \mathrm{g}^{-1} \text {, } \\
30 \mathrm{~min}, 60^{\circ} \mathrm{C} \text {, stirring }\end{array}$ & 3850 & 1250 & $\begin{array}{l}\text { Karacabey } \\
\text { and Mazza } \\
(2008)\end{array}$ \\
\hline 9 & CSLE & Mondeuse & $\begin{array}{l}\text { Dried }\left(50^{\circ} \mathrm{C}\right) \text { for } 24 \mathrm{~h} \text {, } \\
\text { powdered }<0.5 \mathrm{~mm}\end{array}$ & $\begin{array}{l}\text { Ethanol/water } 80: 20 \\
(\mathrm{v} / \mathrm{v}) 30 \mathrm{~mL} \cdot \mathrm{g}^{-1} \\
1 \mathrm{~h}, 60^{\circ} \mathrm{C} \text {, stirring }\end{array}$ & 4600 & 1700 & $\begin{array}{l}\text { Zwingelstein } \\
\text { et al. (2019) }\end{array}$ \\
\hline 10 & CSLE & Loureiro & $\begin{array}{l}\text { Dried }(\mathrm{rt}), \text { powdered }< \\
8 \mathrm{~mm}\end{array}$ & $\begin{array}{l}\text { Ethanol/water } 60: 40 \\
(\mathrm{v} / \mathrm{v}) 40 \mathrm{~mL} \cdot \mathrm{g}^{-1}, 60 \\
\min , 60{ }^{\circ} \mathrm{C}\end{array}$ & 146 & - & $\begin{array}{l}\text { Jesus et al. } \\
(2019)\end{array}$ \\
\hline 11 & CSLE & Cabernet & Powdered $<4 \mathrm{~mm}$ & $\begin{array}{l}\text { Ethanol } 7 \mathrm{~mL} \cdot \mathrm{g}^{-1}, 20 \\
\mathrm{~h}, 30^{\circ} \mathrm{C} \text {, stirring }\end{array}$ & 840 & - & $\begin{array}{l}\text { Izard and } \\
\text { Fourneron } \\
(2001)\end{array}$ \\
\hline 12 & CSLE & Merlot & - & $\begin{array}{l}\text { Ethanol } 8 \mathrm{~mL} \cdot \mathrm{g}^{-1} \text {, } \\
\text { overnight, stirring ( } 3 \\
\text { times) }\end{array}$ & 3520 & 1954 & $\begin{array}{l}\text { Vercauteren } \\
\text { and Salmi } \\
(2012)\end{array}$ \\
\hline 13 & $\begin{array}{l}\text { CSLE } \\
\text { Soxhlet }\end{array}$ & $\begin{array}{l}\text { Cabernet } \\
\text { Moravia }\end{array}$ & $\begin{array}{l}\text { Dried }(\mathrm{rt}) \text { for } 2.5 \\
\text { months and } \\
\text { lyophilizated, } \\
\text { powdered }<1 \mathrm{~mm}\end{array}$ & $\begin{array}{l}\text { Methanol } 67 \mathrm{~mL} \cdot \mathrm{g}^{-1} \text {, } \\
10 \text { cycles }(2-3 \mathrm{~h})\end{array}$ & 5170.5 & 1822.8 & $\begin{array}{l}\text { Soural et al. } \\
(2015)\end{array}$ \\
\hline 14 & $\begin{array}{l}\text { CSLE } \\
\text { Soxhlet }\end{array}$ & $\begin{array}{l}\text { Pool of } \\
\text { Grenache, } \\
\text { Mencia and } \\
\text { Albarino }\end{array}$ & $\begin{array}{l}\text { Stored (rt, in the dark) } \\
\text { until needed, } \\
\text { powdered }<2 \mathrm{~mm}\end{array}$ & $\begin{array}{l}\text { Ethanol/water 50:50 } \\
(\mathrm{v} / \mathrm{v}) 20 \mathrm{~mL} \cdot \mathrm{g}^{-1}, 45 \\
\text { cycles, }(3 \mathrm{~h})\end{array}$ & 1875 & 1855 & $\begin{array}{l}\text { Rodríguez- } \\
\text { Cabo et al. } \\
(2018)\end{array}$ \\
\hline 15 & $\begin{array}{l}\text { CSLE } \\
\text { Soxhlet }\end{array}$ & $\begin{array}{l}\text { Cabernet } \\
\text { Moravia }\end{array}$ & $\begin{array}{l}\text { Dried (rt) for } 4 \\
\text { months, powdered < } \\
0.5 \mathrm{~mm} \\
\text { Moistened at } 11.2 \% \\
\text { with water before } \\
\text { extraction }\end{array}$ & Ethanol $46 \mathrm{~mL} \cdot \mathrm{g}^{-1}, 8 \mathrm{~h}$ & 2310 & 1560 & $\begin{array}{l}\text { Zachová et } \\
\text { al. (2018) }\end{array}$ \\
\hline 16 & UAE & Pinot Noir & $\begin{array}{l}\text { Chopped to pieces (10- } \\
20 \mathrm{~cm} \text { ), stored (rt, in } \\
\text { the dark) for up to } 6 \\
\text { months and } \\
\text { lyophilized, powdered } \\
<1.5 \mathrm{~mm}\end{array}$ & $\begin{array}{l}\text { Ethanol/water } 80: 20 \\
(\mathrm{v} / \mathrm{v}) 10 \mathrm{~mL} \cdot \mathrm{g}^{-1}, \\
5 \mathrm{~min}, 20 \mathrm{kHz}, 80 \mathrm{~W} \\
\text { (4 times) }\end{array}$ & 1908 & 2790 & $\begin{array}{l}\text { Ewald et al. } \\
\text { (2017) }\end{array}$ \\
\hline
\end{tabular}




\begin{tabular}{|c|c|c|c|c|c|c|c|}
\hline 17 & UAE & Gewurztraminer & $\begin{array}{l}\text { Stored (rt, in the dark) } \\
\text { for } 2-4 \text { months, } \\
\text { powdered }<0.84 \mathrm{~mm}\end{array}$ & $\begin{array}{l}\text { Ethanol/water } 80: 20 \\
(\mathrm{v} / \mathrm{v}) 8 \mathrm{~mL} \cdot \mathrm{g}^{-1} \\
5 \mathrm{~min}, 50 \mathrm{kHz}, \mathrm{rt}(4 \\
\text { times) }\end{array}$ & $\begin{array}{l}3275- \\
6533\end{array}$ & $700-824$ & $\begin{array}{l}\text { Vergara et } \\
\text { al. }(2012)\end{array}$ \\
\hline 18 & UAE & Pinot Noir & $\begin{array}{l}\text { Cut into } 25 \mathrm{~cm} \text { pieces } \\
\text { and stored (constant } \\
\text { climate chamber) for } \\
75 \text { days at relative } \\
\text { ambient humidity of } \\
60 \% \text {, freeze-dried and } \\
\text { powdered }\end{array}$ & $\begin{array}{l}\text { Ethanol/water } 80: 20 \\
(\mathrm{v} / \mathrm{v}) 8 \mathrm{~mL} \cdot \mathrm{g}^{-1} \\
5 \mathrm{~min}, 50 \mathrm{kHz}, \mathrm{rt}(4 \\
\text { times) }\end{array}$ & 5453 & - & $\begin{array}{l}\text { Sáez et al. } \\
(2018)\end{array}$ \\
\hline 19 & UAE & Grenache Blanc & $\begin{array}{l}\text { Cut into } 10 \times 5 \mathrm{~mm} \\
\text { cylinders, dried at } 91 \%\end{array}$ & $\begin{array}{l}\text { Water (with } 0.1 \mathrm{M} \text { of } \\
\mathrm{NaOH}) 20 \text { g.g } \mathrm{g}^{-1} \text {, } \\
180 \mathrm{~min}, 50{ }^{\circ} \mathrm{C}, 24 \\
\mathrm{kHz}, 400 \mathrm{~W}\end{array}$ & 24 & - & $\begin{array}{l}\text { Rajha et al. } \\
(2014)\end{array}$ \\
\hline 20 & UAE & $\begin{array}{l}\text { Muscat Vitis } \\
\text { amurensis }\end{array}$ & $\begin{array}{l}\text { Freeze-dried, } \\
\text { powdered }<0.42 \mathrm{~mm}\end{array}$ & $\begin{array}{l}\text { Methanol } 15 \mathrm{~mL} \cdot \mathrm{g}^{-1} \text {, } \\
25 \mathrm{~min}, 60 \mathrm{kHz}(3 \\
\text { times, twice in } 10 \mathrm{~mL})\end{array}$ & 18.9 & - & $\begin{array}{l}\text { Ji et al. } \\
(2014)\end{array}$ \\
\hline 21 & UAE & Malbec & $\begin{array}{l}\text { Cut into pieces, freeze- } \\
\text { dried, powdered }\end{array}$ & $\begin{array}{l}\text { Ethanol/water 60:40 } \\
(\mathrm{v} / \mathrm{v}) 40 \mathrm{~mL} \cdot \mathrm{g}^{-1}, 10 \\
\min , 75^{\circ} \mathrm{C}, 24 \mathrm{kHz} \\
200 \mathrm{~W}\end{array}$ & 664.9 & 2253.9 & $\begin{array}{l}\text { Piñeiro et al. } \\
\text { (2016) }\end{array}$ \\
\hline 22 & UAE & Merlot & - & $\begin{array}{l}\text { Ethanol } 8 \mathrm{~mL} \cdot \mathrm{g}^{-1}, 15 \\
\text { min, ultrasound ( } 3 \\
\text { times) }\end{array}$ & 1207 & 640 & $\begin{array}{l}\text { Vercauteren } \\
\text { and Salmi } \\
(2012)\end{array}$ \\
\hline 23 & MAE & Tinta Roriz & $\begin{array}{l}\text { Dried }\left(50{ }^{\circ} \mathrm{C} \text { in oven }\right) \\
\text { for } 24 \mathrm{~h} \text {, powdered }<1 \\
\mathrm{~mm}\end{array}$ & $\begin{array}{l}\text { Ethanol/water } 60: 40 \\
(\mathrm{v} / \mathrm{v}) 200 \mathrm{~mL} \cdot \mathrm{g}^{-1} \\
20 \mathrm{~min}, 100^{\circ} \mathrm{C}, 1500 \\
\mathrm{~W}\end{array}$ & 1360 & - & $\begin{array}{l}\text { Moreira et } \\
\text { al. (2018) }\end{array}$ \\
\hline 24 & MAE & Gewurztraminer & $\begin{array}{l}\text { Cut into pieces and } \\
\text { freeze-dried, powdered }\end{array}$ & $\begin{array}{l}\text { Ethanol/water } 80: 20 \\
(\mathrm{v} / \mathrm{v}) 125 \mathrm{~mL} \cdot \mathrm{g}^{-1}, \\
5 \mathrm{~min}(\text { and } 2 \mathrm{~min} \text { of } \\
\text { pre-heat), } 125^{\circ} \mathrm{C}, 750 \\
\mathrm{~W}, 3300 \mathrm{rpm}\end{array}$ & 5361 & 2567 & $\begin{array}{l}\text { Piñeiro et al. } \\
\text { (2017) }\end{array}$ \\
\hline 25 & MAE & $\begin{array}{l}\text { Cabernet } \\
\text { Moravia }\end{array}$ & $\begin{array}{l}\text { Dried }(\mathrm{rt}) \text { for } 2.5 \\
\text { months and } \\
\text { lyophilizated, } \\
\text { powdered }<1 \mathrm{~mm}\end{array}$ & $\begin{array}{l}\text { Methanol } 33 \mathrm{~mL} \cdot \mathrm{g}^{-1} \text {, } \\
\text { ramp time } 20 \mathrm{~min} \text {, } \\
\text { hold time } 10 \mathrm{~min}, 150 \\
\text { W }\end{array}$ & 5505.7 & 1962.5 & $\begin{array}{l}\text { Soural et al. } \\
(2015)\end{array}$ \\
\hline 26 & MAE & Loureiro & $\begin{array}{l}\text { Dried }(\mathrm{rt}), \text { powdered }< \\
8 \mathrm{~mm}\end{array}$ & $\begin{array}{l}\text { Ethanol/water } 60: 40 \\
(\mathrm{v} / \mathrm{v}) 40 \mathrm{~mL} \cdot \mathrm{g}^{-1}, 10 \\
\min , 60^{\circ} \mathrm{C}, 1450 \mathrm{~W}\end{array}$ & 336 & - & $\begin{array}{l}\text { Jesus et al. } \\
(2019)\end{array}$ \\
\hline 27 & PSE & Pinot Noir & $\begin{array}{l}\text { Freeze-dried, } \\
\text { powdered } \sim 0.26 \mathrm{~mm}\end{array}$ & $\begin{array}{l}\text { Ethanol/water } 25: 75 \\
(\mathrm{v} / \mathrm{v}) 30 \mathrm{~mL} \cdot \mathrm{g}^{-1} \\
5.2 \mathrm{MPa}, 1 \mathrm{~mL} \cdot \mathrm{min}^{-1} \text {, } \\
105^{\circ} \mathrm{C}\end{array}$ & 3400 & 1650 & $\begin{array}{l}\text { Karacabey et } \\
\text { al. (2012) }\end{array}$ \\
\hline 28 & PSE & $\begin{array}{l}\text { Cabernet } \\
\text { Moravia }\end{array}$ & $\begin{array}{l}\text { Dried }(\mathrm{rt}) \text { for } 2.5 \\
\text { months and } \\
\text { lyophilizated, } \\
\text { powdered }<1 \mathrm{~mm}\end{array}$ & $\begin{array}{l}\text { Methanol } 19 \mathrm{~mL} . \mathrm{g}^{-1} \\
10-10.5 \mathrm{MPa}, 100{ }^{\circ} \mathrm{C} \\
15 \mathrm{~min}\end{array}$ & 6032.3 & 2059.8 & $\begin{array}{l}\text { Soural et al. } \\
(2015)\end{array}$ \\
\hline 29 & PSE & Pool of & Stored (rt, in the dark) & Ethanol/water 50:50 & 1215 & 2141 & Rodríguez- \\
\hline
\end{tabular}




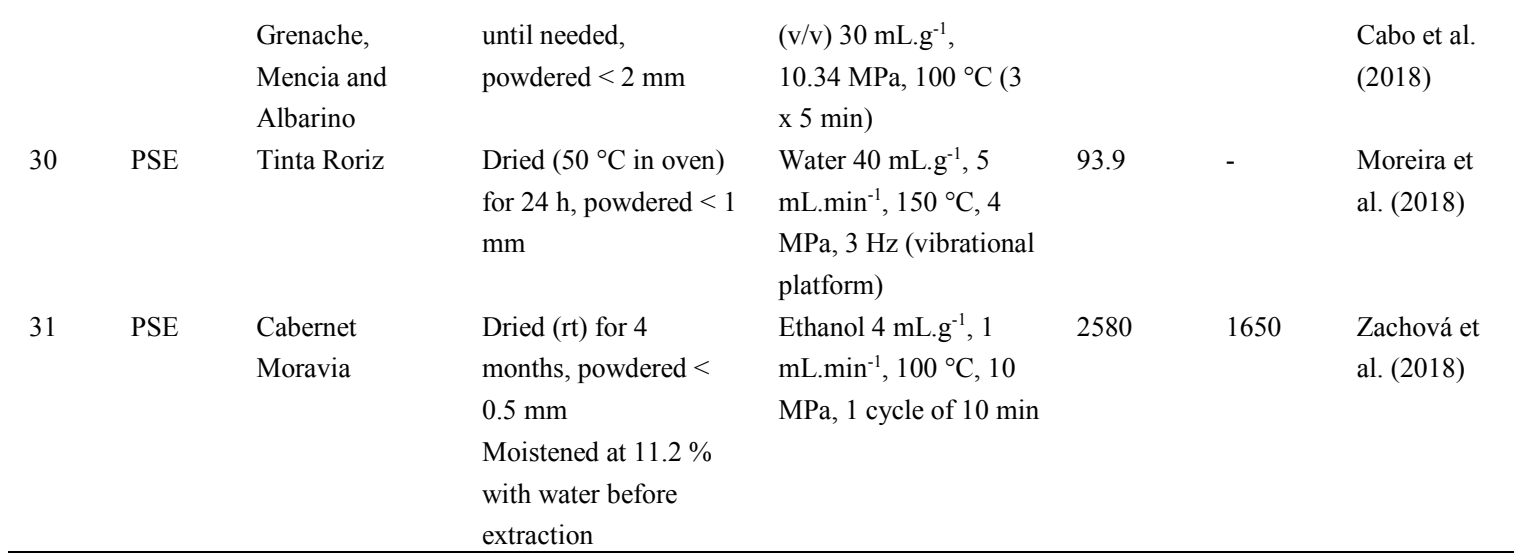

\section{Emerging methods of extraction}

During the last ten years, emerging technologies such as ultrasound or microwaves have gained interest since they could potentially overcome the conventional extraction disadvantages (Galanakis, 2017; Zuin and Ramin, 2018). This section focuses on the emerging methods used to extract Rsv, Vf and total polyphenols from grape canes and discusses their advantages and limits.

\subsection{Ultrasound-assisted extraction (UAE)}

Ultrasound technology is a promising method to extract compounds of interest from biomass (Rombaut et al., 2014; Chemat et al., 2017). Thanks to the cavitation phenomenon, which is the growth, the oscillation and finally the collapse of gaseous bubbles subjected to a pressure wave in a liquid, ultrasound can particularly improve the mass transfer in solid-liquid systems (Draye et al., 2009; Bussemaker and Zhang, 2013). Sonochemical extraction, also called ultrasound-assisted extraction (UAE) in the literature, presents some interesting advantages in terms of efficient and green extractions: (i) enhancement of extraction yield, (ii) enhancement of aqueous extraction 
processes limiting the use of organic solvents for some cases, (iii) opportunity to use alternative and eco-friendly solvents by improving their extraction performance and (iv) enhancement of the heat-sensitive molecules extraction under conditions that would otherwise have low yields (Chatel, 2017). This technology is attractive to extract various molecules and biomaterials from biomass, including polysaccharides, essential oils, proteins and peptides, metals, bioactive molecules and fine chemicals (Gogate and Kabadi, 2009; Shirsath et al., 2012). Polyphenols appear to be stable and undergo no degradation under ultrasonic bath treatment (Biesaga and Pyrzyńska, 2013). UAE has been recently investigated for grapevine waste. As indicated in Table 1 (Entries 16-22), in the literature frequencies between $20 \mathrm{kHz}$ and $80 \mathrm{kHz}$ are used to extract transresveratrol and trans- $\varepsilon$-viniferin from grape canes. This range of frequencies belonging to "low frequencies" promotes mechanical effects such as shock waves or microjets, which induce a greater penetration of solvent into plant material (Wang and Weller, 2006). However, besides frequency, many factors can influence ultrasound efficiency such as sonication time, acoustic power, duty cycle, temperature, the type of equipment (bath, cup-horn, probe, tubular, etc.) and the geometry of the reactor (Sutkar and Gogate, 2009). According to Table 1, Entries 16-22, UAE is usually less timeconsuming than CSLE. However, in the case of these particular studies, no comparison is made with a classical method (under silent conditions) to highlight the ultrasonic effects. In addition, ultrasonic parameters are not optimized and often used as routine protocols in ultrasonic baths (Vergara et al., 2012, Ewald et al., 2017; Sáez et al., 2018). However, it is known that ultrasonic baths deliver low power in the medium and are 
then less efficient than ultrasonic probe (Rombaut et al., 2014). Piñeiro et al. (2016) performed a study on UAE of stilbenes from grape canes under ultrasonic irradiation, at a frequency of $24 \mathrm{kHz}$ and a power of $200 \mathrm{~W}$. However, their study is only focused on the impact of non-ultrasonic parameters such as solvent-to-solid ratio, temperature and solvent composition. The optimized extraction method they developed (Table 1, Entry 21) has a shorter duration (and is more efficient in the case of Rsv recovery) than the CSLE of Lambert et al. (2013) they used to compare. Nevertheless, there is no doubt that temperature and solvent composition that are not the same between the two technics (ethanol and water at $75{ }^{\circ} \mathrm{C}$ for UAE and acetone and water at room temperature for CSLE) could be responsible for this difference. Piñeiro et al. (2013) elaborated a fractional factorial experimental design to study more precisely the impact of the different ultrasonic parameters of ultrasound generation system of $200 \mathrm{~W}$ and $24 \mathrm{kHz}$ on the extraction of four stilbenes from grape stems. These settings include temperature $\left(5-80{ }^{\circ} \mathrm{C}\right)$, electrical power (amplitudes $\left.30-70 \%\right)$, intervals between pulses $(0.2-0.7 \mathrm{~s})$, diameter of probe tip (2-7 mm), solvent-to-solid ratio $\left(15-30 \mathrm{~mL} \cdot \mathrm{g}^{-1}\right)$, ethanol content in water (30-80\%) and duration (15-30 min). As for CSLE, ethanol percentage of $80 \%$ is the most efficient but the highest solvent-to-solid ratio is also necessary. In their case, cycle, amplitude and probe tip have minimal influence. Nevertheless, the extraction time is drastically reduced and their optimized conditions are as follows: a single $15 \mathrm{~min}$ cycle with pulses every $0.7 \mathrm{~s}$ at $75^{\circ} \mathrm{C}, 30 \mathrm{~mL} \cdot \mathrm{g}^{-1}$ as solvent-to-solid ratio, ethanol/water $80: 20(\mathrm{v} / \mathrm{v})$ as solvent, $7 \mathrm{~mm}$ diameter for the probe tip and $70 \%$ of the maximal 
electrical power. This optimization conducts to an upgrade of $19 \%$ in Rsv extraction in only 15 min when compared with a conventional extraction of $60 \mathrm{~min}$.

The same tendency was observed by Cho et al. (2006) on Rsv recovery from grapes for a higher frequency $\left(47 \mathrm{kHz}, 8 \mathrm{~g} . \mathrm{L}^{-1}\right.$ of ethanol/water $80: 20(\mathrm{v} / \mathrm{v})$ at room temperature and $14 \mathrm{~W} . \mathrm{L}^{-1}$ as volume acoustic power). However, several works on the study of UAE of Rsv, Vf and total polyphenols from grape canes mention that ultrasound do not efficiently improve the extraction of these compounds (Delgado-Torre et al., 2012; Vercauteren and Salmi, 2012, Pawlus et al., 2013; Rajha et al., 2014). Caudalie's patent (Table 1, Entries 12 and 22) compared overnight maceration of Merlot grape canes with 15 min UAE in the same conditions and obtained $3520 \mathrm{mg}(\mathrm{Rsv}) \cdot \mathrm{kg}^{-1}, 1954 \mathrm{mg}(\mathrm{Vf}) \cdot \mathrm{kg}^{-1}$, $1207 \mathrm{mg}(\mathrm{Rsv}) \cdot \mathrm{kg}^{-1}$ and $640 \mathrm{mg}(\mathrm{Vf}) \cdot \mathrm{kg}^{-1}$ respectively. Pawlus et al. (2013) also noted that ultrasound irradiation does not enhance efficiency but increases experiments reproducibility of stilbenes extraction from various grape canes varieties. It could be supposed that ultrasound potential depends on the raw materials composition. Indeed, grape canes are composed of $34 \%$ of cellulose, $19 \%$ of hemicellulose and $27 \%$ of lignin whereas grape stems for example are composed of $30 \%, 35 \%$ and $23 \%$ of the same polymers respectively (Couto et al., 2003; Max et al., 2010). On the other hand, Vergara et al. (2012) found very good levels of Rsv from 3275 to $6533 \mathrm{mg}_{(\mathrm{Rsv})} \cdot \mathrm{kg}^{-1}$ (Table 1, Entry 17) in Gewurztraminer grape canes in 5 min UAE (cycle repeated 4 times) but did not compare their method with a classical extraction. To the best of our knowledge the studies of Rajha et al. (2014) and Piñeiro et al. (2016) are the only ones concerning 
UAE comparison with CSLE of concerned stilbenes from grape canes highlighting a clear lack of comparison in this field.

Consequently, it appears that the main advantage of UAE for the mentioned application is its rapidity but further investigations are needed to understand the individual effect of each ultrasonic parameter. For example, the study of the impact of frequency as it was achieved by Tungmunnithum et al. (2019) on trans-rosmarinic acid extraction from painted nettle leaves is not yet performed for the discussed application. Another missing point is the investigation of acoustic power influence. Indeed, it is known that the ultrasonic power incurs losses specific to each ultrasonic system and leading to considerable differences between the electric power provided by the generator and the power really delivered into the extraction media (Luche, 1998). Then, it requires the calculation of the acoustic power, which is function of the value of the solvent mass heat capacity to produce consistent and comparable UAE results.

Additionally, energy consumption of this technique is generally not considered and has also to be compared to conventional heating and stirring as it was made by Cousin et al. (2019) or Bhalerao et al. (2018) for the synthesis of epoxides. According to Table 1, Entries 15-22, solvent-to-solid ratio (around $30 \mathrm{~mL} \cdot \mathrm{g}^{-1}$ on average) is the same. Ultimately and as for CSLE, the question of purification remains unresolved.

\subsection{Microwave-assisted extraction (MAE)}

Microwaves are non-ionizing electromagnetic waves $(0.3-300 \mathrm{GHz}$, usually $2.45 \mathrm{GHz}$ in commercial systems) that interact with polar molecules to create heat and can 
efficiently penetrate plant materials to disrupt molecule-matrix interactions (Wang and Weller, 2006). Microwaves emerge as a powerful technique for transformations in organic chemistry and for extraction processes (MAE) (Draye and Bazureau, 2012; Spargo, 2004). Their use generally leads to (i) reduction of reaction times, (ii) enhancement of conversion, yield and selectivity, (iii) environmental advantages limiting the uses or the amounts of some solvents through a homogeneous heat (Letellier and Budzinski, 1999). In the literature, the number of MAE examples from biomass increases from year to year, from laboratory to pilot scales (Bouras et al., 2015). In 2017, Piñeiro et al. (2017) performed an integral study of the MAE of Rsv and Vf from various grape canes varieties by using an experimental design plan to test several settings as ethanol content in water (50-80\%), magnetic stirring level (1650$3300 \mathrm{rpm})$, temperature $\left(50-150{ }^{\circ} \mathrm{C}\right)$, extraction duration $(5-35 \mathrm{~min})$, microwave power $(750-1500 \mathrm{~W})$, solvent-to-solid ratio $\left(25-125 \mathrm{~mL} \cdot \mathrm{g}^{-1}\right)$. In the same manner as for UAE and conventional extraction, ethanol/water 80:20 (v/v) and the highest solvent-to-solid ratio $\left(125 \mathrm{~mL} \cdot \mathrm{g}^{-1}\right)$ were chosen since the total stilbenes content positively evolved as they increased. A temperature of $125^{\circ} \mathrm{C}$ was selected because at higher temperature, the authors found that stilbenes levels started to decrease. They also showed that increasing the power from $750 \mathrm{~W}$ (50\% of nominal power) to $1500 \mathrm{~W}$ (100\% of nominal power) involved a lower extraction of stilbenes. Finally, an extraction time of 5 min was enough to observe the same recovery efficiency than in $35 \mathrm{~min}$ at $750 \mathrm{~W}$. Their optimized conditions were as set out in Table 1, Entry 24 and allowed to enhance up to $36 \%$ the recovery of Rsv and Vf compared to a CSLE. But the latter was performed 
using the extraction conditions of Lambert et al. (2013) (Table 1, Entry 4), namely in very different conditions than the MAE of Piñeiro et al. (2017). The same confusion was observed in the work of Moreira et al. (2018) who compared their MAE (Table 1, Entry 23) to their CSLE (Table 1, Entry 5) with different temperature, solvent-to-solid ratio and ethanol content. Then, it is hard to know the impact of microwaves irradiation for the discussed purpose. Thanks to experimental design, Jesus et al. (2019) recently performed an interesting and complete comparison between CSLE and MAE for the recovery of bioactive compounds such as Rsv from Loureiro grape canes powdered at 8 $\mathrm{mm}$. Their results show that under the same conditions (ethanol/water 60:40 (v/v) 40 $\left.\mathrm{mL} \cdot \mathrm{g}^{-1}, 60^{\circ} \mathrm{C}\right) \mathrm{MAE}$ duration is shorter (10 min against $\left.60 \mathrm{~min}\right)$ and more efficient (336 mg.kg ${ }^{-1}$ against $146 \mathrm{mg} \cdot \mathrm{kg}^{-1}$ ) to extract Rsv (Table 1, Entries 10 and 26). Moreover, all their MAE combinations (even the less efficient) give higher yields of Rsv than the best conditions with CSLE. It could be supposed that MAE is more efficient on rough particles sizes than CSLE.

Nevertheless, extraction duration seems to be related to the microwave power level. Indeed, contrary to the previous work of Piñeiro et al. (2017) at $750 \mathrm{~W}$, Sánchez-Gómez et al. (2014) showed that at $600 \mathrm{~W}$ a longer time (from $5 \mathrm{~min}$ to $15 \mathrm{~min}$ ) of MAE entailed a better stilbenes extraction from Airén white grape canes. However, they did not investigate the impact of other settings. Furthermore, Delgado-Torre et al. (2012) noticed that the increase of microwave power $(60-140 \mathrm{~W})$ improves phenolic compounds extraction for short durations $(5 \mathrm{~min})$ but has almost no effect for long durations (15 min). In the case of the study of Soural et al. (2015) (Table 1, Entries 13 
and 25), a MAE with solvent-to-solid ratio half that those of CSLE enabled an increase of $6 \%$ in Rsv and Vf extraction with a duration reduced from 2-3 h to $30 \mathrm{~min}$. The work of Delgado-Torre et al. (2012) evaluated several non-conventional methods to extract phenolic compounds from various grape canes varieties. According to their data and under the same conditions, MAE would be less efficient than UAE for this purpose. But here again, results are expressed in $\mathrm{mg}_{(\mathrm{GAE})} \cdot \mathrm{g}^{-1}$ and do not necessarily involve the same trend for Rsv and Vf yields. Despite the divergent action mechanisms between the two auxiliary energies, these opposed results could also be related to the different powers of equipment. Indeed, the authors set microwave power at $140 \mathrm{~W}$ and ultrasonic power at $280 \mathrm{~W}$. Interestingly, Alexandru et al. (2014) observed the opposite tendency but with a power of $1500 \mathrm{~W}$ for MAE and $80-100 \mathrm{~W}$ for UAE. This finding could be related to the work of Piñeiro et al. (2017) and a possible degradation of compounds with such energy input.

Ultimately, it seems that the conclusion about MAE is approximately the same than for UAE. Some works using MAE of Rsv and Vf from grape canes do not compare their method with other techniques or compare them in inaccurate conditions (Cebrián et al., 2017; Piñeiro et al., 2017; Moreira et al., 2018). If MAE appears to significantly reduce extraction duration, solvent-to-solid ratios remain generally high $\left(5-200 \mathrm{~mL} \cdot \mathrm{g}^{-1}\right)$.

\subsection{Pressurized solvent extraction (PSE)}

PSE is also named pressurized liquid extraction (PLE) or accelerated solvent extraction (ASE). In the case where water is used as solvent, it could also be called pressurized hot 
water extraction (PHWE), sub-critical water extraction (SWE) or superheated water extraction (SHWE) (Guardia and Armenta, 2010). Nevertheless, for all the principle is the same; it is based on a pressurized extraction chamber $(10-15 \mathrm{MPa})$ that maintains solvent in a liquid state at a temperature higher than its boiling point. Then, the extraction efficiency is increased by an enhancement of the mass transfer and solubility of compounds in the medium (Mustafa and Turner, 2011). Concerning trans-resveratrol and trans- $\varepsilon$-viniferin extraction from grape canes, there are some works investigating the use of PSE for that purpose. Karacabey et al. (2012) proposed Rsv and Vf extraction from Pinot Noir grape canes with their "Pressurized Low-Polarity Water extraction". Using conditions described in Table 1, Entry 27 (ethanol/water 25:75 (v/v) $30 \mathrm{~mL} \cdot \mathrm{g}^{-1}$ pumped at $1 \mathrm{~mL} \cdot \mathrm{min}^{-1}$ at $105{ }^{\circ} \mathrm{C}$ under $5.2 \mathrm{MPa}$ ), it is demonstrated that diffusivity is higher than in a CSLE using ethanol/water 80:20 (v/v) $125 \mathrm{~mL} \cdot \mathrm{g}^{-1}$ during $30 \mathrm{~min}$ at 60 ${ }^{\circ} \mathrm{C}$ under stirring. With their new process, the authors observed a $13 \%$ loss in Rsv contents in their extracts whereas a 1.5-fold increase of $\mathrm{Vf}$ levels is mentioned in comparison with their reference method. It is also notable that $\mathrm{Vf}$ yields are more impacted by changes of temperature, flow rate and ethanol/water ratio than Rsv yields. However, several parameters between the two techniques are different as ethanol content, temperature and solvent-to-solid ratio and authors do not exclude thermal degradation of Rsv at such temperature (Karacabey and Mazza, 2008; Karacabey et al., 2012). An improvement of Rsv and Vf extraction yields (around $10 \%$ and $5 \%$ respectively) from grape canes was measured by Zachová et al. (2018) by using $10 \mathrm{~min}$. of PSE with ethanol $4 \mathrm{~mL} \cdot \mathrm{g}^{-1}$ pumped at $1 \mathrm{~mL} \cdot \mathrm{min}^{-1}$ at $100^{\circ} \mathrm{C}$ under $10 \mathrm{MPa}$ instead of 
$8 \mathrm{~h}$ of Soxhlet extraction with ethanol $46 \mathrm{~mL} \cdot \mathrm{g}^{-1}$ (Table 1, Entries 15 and 31). Their study suggests that for the same temperature $\left(80^{\circ} \mathrm{C}\right)$ and the same solvent composition (100\% ethanol) the pressure increase in PSE would slightly improve Rsv and Vf extraction in comparison with Soxhlet system. This improvement could also be due to a shorter duration ( $5 \mathrm{~min}$ for PSE and $8 \mathrm{~h}$ for Soxhlet) that would preserve the compounds. It is also notable that a pressure exceeding $10 \mathrm{MPa}$ is unfavorable for the discussed purpose. Moreira et al. (2018) proposed to compare several green extraction techniques on two grape canes varieties including PSE. The method developed (Table 1, Entry 30) consisting in water $40 \mathrm{~mL} \cdot \mathrm{g}^{-1}$ at $150{ }^{\circ} \mathrm{C}$ under $4 \mathrm{MPa}$ seems to be clearly inefficient to extract Rsv when compared to MAE (Table 1, Entry 23) and CSLE (Table 1, Entry 5) with respectively 93.9, 1360 and $1330 \mathrm{mg}_{(\mathrm{Rsv})} \cdot \mathrm{kg}^{-1}$. In this example again, the conditions between methods are completely different to enable a consistent comparison. Soural et al. (2015) used pure methanol $19 \mathrm{~mL} \cdot \mathrm{g}^{-1}$ at $100{ }^{\circ} \mathrm{C}$ under $10-10.5$ MPa during 3 cycles of 5 min (Table 1, Entry 25) to extract Rsv and Vf from Cabernet Moravia grape canes. Their work shows the opposite result when compared to 10 cycles (2-3 h) Soxhlet extraction in pure methanol $67 \mathrm{~mL} \cdot \mathrm{g}^{-1}$ (Table 1, Entry 13) with respectively $6032 \mathrm{mg}(\mathrm{Rsv}) \cdot \mathrm{kg}^{-1}$ and $2060 \mathrm{mg}(\mathrm{Vf}) \cdot \mathrm{kg}^{-1}$ and $5171 \mathrm{mg}(\mathrm{Rsv}) \cdot \mathrm{kg}^{-1}$ and 1823 $\mathrm{mg}(\mathrm{Vf}) \cdot \mathrm{kg}^{-1}$. This could be related to the increase of the temperature from limited $64.7^{\circ} \mathrm{C}$ (the boiling point of methanol under atmospheric pressure) in the Soxhlet process to 100 ${ }^{\circ} \mathrm{C}$ in the pressurized system. Finally, the work of Rodríguez-Cabo et al. (2018) describes opposite behaviors of the two compounds under the two extraction processes. Using PSE in ethanol/water 50:50 (v/v) $30 \mathrm{~mL} \cdot \mathrm{g}^{-1}$ at $100{ }^{\circ} \mathrm{C}$ under $10.34 \mathrm{MPa}$ during 3 
cycles of 5 min (Table 1, Entry 29) Rsv levels are lower than for a Soxhlet extraction (Table 1, Entry 14) whereas Vf levels are higher. The previous contrasted results could be explained by a lower degradation temperature for Rsv $\left(105^{\circ} \mathrm{C}\right)$ than for $\operatorname{Vf}\left(150^{\circ} \mathrm{C}\right)$ (Karacabey et al., 2012).

The performances of PSE are still questionable in the case of the targeted molecules. As CSLE, it requires high volumes of solvent (from $19 \mathrm{~mL} \cdot \mathrm{g}^{-1}$ to $40 \mathrm{~mL} \cdot \mathrm{g}^{-1}$ ) and also high temperatures (from $100{ }^{\circ} \mathrm{C}$ to $150{ }^{\circ} \mathrm{C}$ ) that could be incompatible with thermal stability of compounds as discussed above.

\subsection{Comparison of UAE, MAE and PSE methods}

The three discussed emerging methods are promising. As mentioned in the Table 2, their main advantage in the case of the extraction of Rsv and Vf from grape canes is their shorter extraction times in comparison to classical approach. According to Chemat et al. (2012), these methods could also considerably reduce energy consumption even if this parameter is not always studied in each application reported in the literature. In comparison with CSLE, solvent-to-solid ratios remain high (around $30 \mathrm{~mL}^{-1} \mathrm{~g}^{-1}$ on average) especially in the case of MAE (around $100 \mathrm{~mL} \cdot \mathrm{g}^{-1}$ on average). However, a solvent-free process is possible with MAE in some cases thanks to constitutive water of samples (Rombaut et al., 2014). With novel devices, MAE can combine microwaves irradiation and the control of pressure and temperature as for PSE (Eskilsson et al., 2000). PSE and MAE have the advantage to be quite simple to set up while UAE has 
numerous parameters to adjust. In addition, the impact of parameters proper to each method is still misunderstood and needs to be studied more deeply.

Table 2. Comparison of the three emerging methods for the extraction of Rsv and Vf from grape canes according to our personal analysis of the existing literature

\begin{tabular}{|c|c|c|c|}
\hline $\begin{array}{l}\text { Characteristics for the } \\
\text { discussed application }\end{array}$ & $U A E$ & $M A E$ & PSE \\
\hline Action modes & $\begin{array}{l}\text { Cavitation that can cause } \\
\text { cells disruption } \\
\text { Hot spots }\end{array}$ & $\begin{array}{l}\text { Electromagnetic field that } \\
\text { interacts selectively with } \\
\text { polar entities (solvent, } \\
\text { compounds and matrices) } \\
\text { and can cause cells } \\
\text { disruption } \\
\text { Hot spots }\end{array}$ & $\begin{array}{l}\text { High pressure and high } \\
\text { temperature leading to the } \\
\text { possibility to manipulate } \\
\text { dielectric constant of solvents } \\
\text { Improvement of mass } \\
\text { transfer thanks to pressure }\end{array}$ \\
\hline Specific parameters & $\begin{array}{l}\text { Frequency, acoustic power, } \\
\text { duty cycle, design of reactor, } \\
\text { type of emitting source }\end{array}$ & $\begin{array}{l}\text { Power, type of equipment } \\
\text { (closed or open vessels) } \\
\text { involving the possibility to } \\
\text { control the temperature and } \\
\text { the pressure }\end{array}$ & $\begin{array}{l}\text { Pressure, temperature, flow } \\
\text { rate }\end{array}$ \\
\hline Advantages & Fast & $\begin{array}{l}\text { Fast } \\
\text { Efficient for rough particles } \\
\text { size }\end{array}$ & $\begin{array}{l}\text { Fast } \\
\text { No additional step of } \\
\text { filtration is required }\end{array}$ \\
\hline Disadvantages & $\begin{array}{l}\text { Require an additional } \\
\text { temperature controller if } \\
\text { necessary }\end{array}$ & $\begin{array}{l}\text { High volumes of solvent } \\
\text { Require an additional } \\
\text { temperature controller if } \\
\text { necessary }\end{array}$ & $\begin{array}{l}\text { Restrictions due to } \\
\text { pressurized apparatus }\end{array}$ \\
\hline
\end{tabular}

\subsection{Other unconventional methods}

Even if UAE, MAE and PSE are the main novel methods used to extract transresveratrol and trans- $\varepsilon$-viniferin from grape canes, other emerging techniques are studied (Zuin and Ramin, 2018). Rajha et al. (2014) worked on electrical treatments like pulsed electric fields (PEF) and high-voltage electrical discharges (HVED) in alkaline water to enhance polyphenols (including Rsv) release from cut Grenache Blanc grape 
canes. Electrical treatments allowed to extract Rsv in low yields $\left(24-414 \mathrm{mg}_{(\mathrm{Rsv})} \cdot \mathrm{kg}^{-1}\right)$ whereas for untreated samples the compound was not detectable under HPLC analysis. Industrially, Valagro Company set up an extrusion process using 15 min extraction of Melon de Bourgogne grape canes in ethanol/water 80:20 (v/v) followed by a step in a twin-screw extruder $\left(2 \mathrm{~kg} \cdot \mathrm{h}^{-1}, 100 \mathrm{rpm}\right)$ at room temperature. They finally obtained 984 $\mathrm{mg}_{(\mathrm{Rsv})} \cdot \mathrm{kg}^{-1}$ and $7400 \mathrm{mg}(\mathrm{Vf}) \cdot \mathrm{kg}^{-1}$ (Soum et al., 2015). However, between 100 and $1000 \%$ in weight of solvent are required.

On the other hand, LVMH group set up a process under sub-critical $\mathrm{CO}_{2}\left(20^{\circ} \mathrm{C}, 29\right.$ $\mathrm{MPa}$, no co-solvent) to obtain a lipophilic extract from Sauvignon grape canes (Pecher and Andre, 2010). Without giving details of its final composition, the extract is then incorporated in anti-ageing cream suggesting an antioxidant effect. The technique of supercritical fluid extraction (SFE) with $\mathrm{CO}_{2}$ has many advantages like the possible adjustment of pressure and temperature of $\mathrm{CO}_{2}$ that could increase the solubility of compounds. In addition, it is usually less time-consuming than conventional extraction and used very volatile, nontoxic and non-flammable solvent. But its main disadvantage remains the onerous operating conditions required and the need of high solvent-to-solid ratios if no co-solvent is used (Berk, Zeki, 2009; Wang and Weller, 2006). Indeed, Zachová et al. (2018) used SFE with $\mathrm{CO}_{2}\left(50{ }^{\circ} \mathrm{C}, 30 \mathrm{MPa}, 15 \%\right.$ ethanol as co-solvent) to extract stilbenes from Cabernet Moravia grape canes. However, their work highlights the need of high percentage of ethanol to extract Vf. Moreover, their SFE is less efficient than Soxhlet extraction and PSE to recover both compounds. 
Otherwise, Sánchez-Gómez et al. (2014) proposed a dynamic solid-liquid extraction process in water using a Naviglio Extractor. This technique is based on alternative compressions and decompressions of water on solids inside a reactor at room temperature. It appears not suitable for stilbenes extraction in comparison with a conventional extraction in water but favors volatile alcohols (linalool, guaiacol, benzyl alcohol, etc.) extraction.

Finally, it seems that it remains technological barriers in the field of emerging extraction methods investigation. In the case of Rsv and Vf recovery from grape canes, the main improvement brought by UAE, MAE or PSE is a saving of time. Indeed, these novel technics are generally faster and less solvent consuming (Zuin and Ramin, 2018). However, the use of huge amount of solvent is still present in the mentioned examples and accurate comparisons with CSLE need to be further investigated. Energy consumption of these novel techniques has also to be considered (Alexandru et al., 2014; Rajha et al., 2014). All of this could explained the restricted use of these methods for Rsv and Vf recovery from grape canes in industrial processes in addition to the extracts purity concern.

\subsection{What about the purification?}

To conclude, it is important to emphasize that most of the presented studies do not propose any purification process of both compounds from the global extracts. The Caudalie's patent claimed a process involving a polyvinylidene fluoride (PVDF) solid support to purify a crude extract obtained using the method shown in Table 1, Entry 12. 
It allowed getting a final extract enriched in Vf with a purity comprised between $77 \%$ and $100 \%$ in weight (Vercauteren and Salmi, 2012). LVMH group used successive extraction steps in acetone, ethanol/water and acetone/water mixtures, hexane and a silica column to finally get a extract of $68 \%$ of Rsv oligomers and $24 \%$ of "viniferin" from Sauvignon grape canes (Andre and Renimel, 2014). By using successive extractions with different water/ethanol mixture compositions on a Cabernet grape canes extract, the company Actichem obtained an extract with a Rsv content of $2 \%$ (Izard and Fourneron, 2001). It represents $87 \%$ loss with respect to their initial yield (Table 1, Entry 11). Here again, purification requires huge volumes of solvents, sometimes toxic, and is time-consuming. Several works attempted to find alternatives to these multi-steps purification process by elaborating molecularly imprinted polymers (MIPs) to selectively isolate Rsv in peanut press waste extracts or Pinot Noir grape skins extracts (Schwarz et al., 2011a, 2011b; Hashim et al., 2013; Schwarz et al., 2015; Hashim et al., 2016). The results are promising and are industrially feasible but involve additional polymer preparation steps (Hearn et al., 2016). Macke et al. (2012) also proposed to use counter-current chromatography to separate stilbenes present in a commercial grapevine-shoot extract to get enriched fractions. At the last, aqueous twophase systems (ATPS) are also suggested as extraction technic but with the advantage to give a partial purification. Recently, Zhou et al. (2019) proposed ATPS with ethanol and ammonium sulfate to separate Rsv from sugars present in enzymatic hydrolysates of Japanese knotweed under ultrasound irradiation with encouraging results. 


\section{Influencing parameters: what else?}

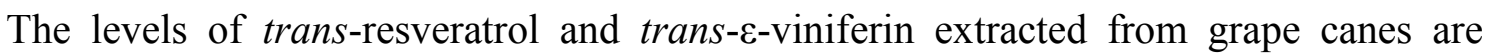
obviously dependent on the extraction method used. However, other influencing parameters have to be considered to compare different results such as growing and biological characteristics, post-pruning treatments, work-up and analyses methods.

\subsection{Growing and biological characteristics}

In addition to the extraction method used, there are many parameters inherent in the use of biological material that drastically influence the obtained yields. The first one is the variety of the vine studied. There are many works showing the variations of the stilbenes contents in canes coming from different type of vines. For example, Pinot Noir and Gewurztraminer are both known to be rich in stilbenes whereas other vines varieties are known to be poor in these polyphenols (Lambert et al., 2013; Piñeiro et al., 2017). However, Vergara et al. (2012) showed considerable variations in stilbenes contents for a same variety and for same extractions conditions. For example, Rsv contents in Gewurztraminer canes can vary from $3275 \mathrm{mg}(\mathrm{Rsv}) \cdot \mathrm{kg}^{-1}$ to $6533 \mathrm{mg}(\mathrm{Rsv}) \cdot \mathrm{kg}^{-1}$ as seen in Table 1, Entry 17. In the same vein, Zwingelstein et al. (2019) recently investigated the impacts of vineyard age ( 5 and 20 years old) and vineyard origin of Jacquère grape canes on their Rsv and Vf contents. They showed that there is an increase of both compounds levels when the vineyard is older. The authors also observed significant differences depending on the vineyard of origin (in this case, two exploitations). These variations could also rely on several parameters such as UV-exposition and soil 


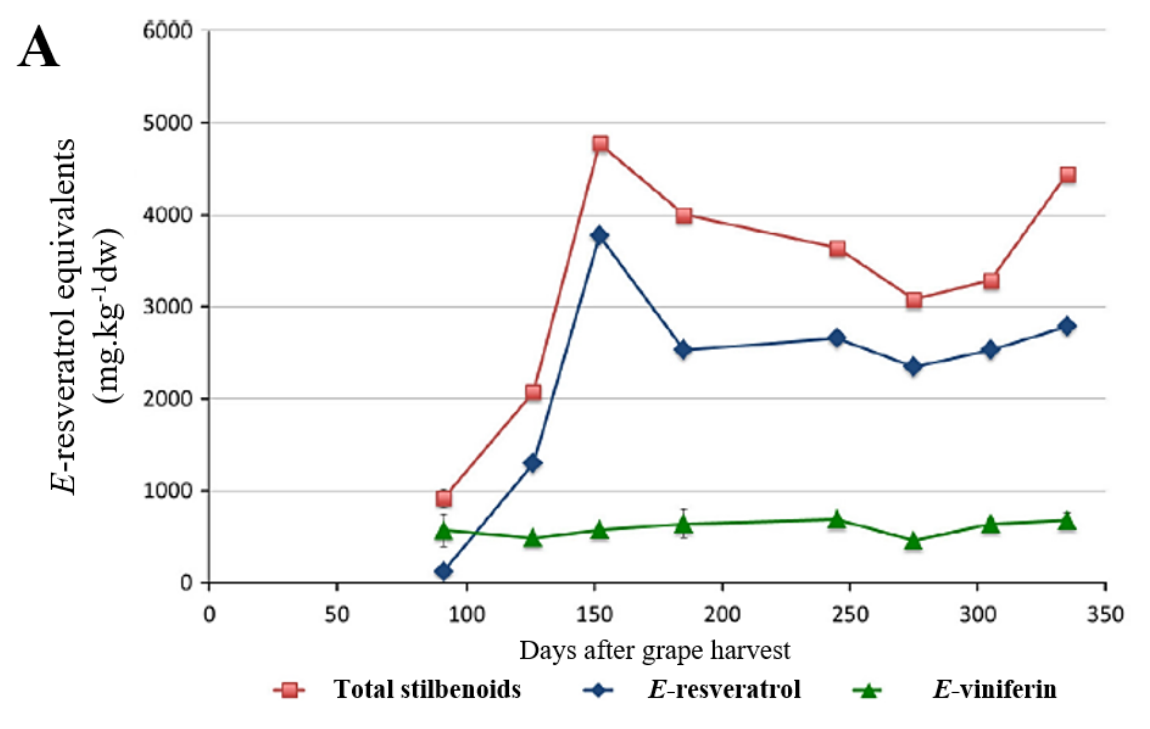

B 4000

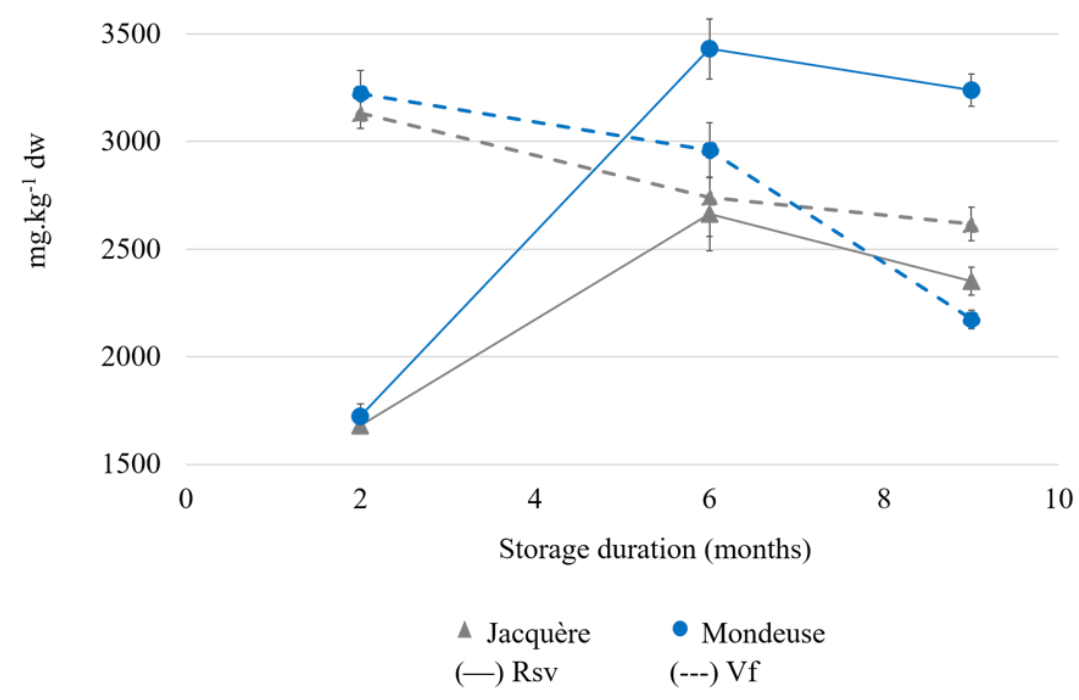

Figure 4. Examples of stilbenoids accumulation in A) Pinot Noir grape canes during storage at room temperature in the work of Gorena et al. (2014) and B) Jacquère and Mondeuse grape canes during storage at room temperature in the work of Zwingelstein et al. (2019). The figures are adapted from the mentioned publications. 
compositions (Guerrero et al., 2010; Acuña-Avila et al., 2016). Diverse viticultural practices as leaf removal or fertilizer use could also be responsible for such stilbenes contents variations (Keller et al., 2000; Cavaliere et al., 2010). Finally, fungal pressure dependent on rainfalls among others drastically impacts the biosynthesis of stilbenes (Houillé et al., 2015b; Rusjan and Mikulic- Petkovsek, 2015; Del-Castillo-Alonso et al., 2016; Ewald et al., 2017).

\subsection{Post-pruning treatments}

Regardless the conditions during culture period, the way the canes are treated after their pruning can alter the accumulation of stilbenes. Numerous studies demonstrate that different times storage of grape canes before extraction could lead to really different levels, especially for Rsv contents (Gorena et al., 2014; Houillé et al., 2015a; Cebrián et al., 2017; Zwingelstein et al., 2019). It seems that there is a pick of accumulation of the compound between 6 weeks and 6 months of storage with an increase of stilbenoid yield up to five-fold mainly due to Rsv (Figure 4) (Vergara et al., 2012; Gorena et al., 2014; Houillé et al., 2015a; Cebrián et al., 2017). All authors assumed that the level of Vf remains more or less stable during the period of their studies echoing the above discussion of better Vf stability. Both compounds accumulation has been shown to be induced by drought stress in grapevine leaves (Hatmi et al., 2015). Houillé et al. (2015b) demonstrated that Vf accumulation in several varieties grape canes increases when a fungal infection occurs whereas Rsv contents decrease. The divergence between compounds accumulation durations could be due to several factors such as temperature, 
UV exposition or relative humidity of storage location (Guerrero et al., 2010; Houillé et al., 2015a; Sáez et al., 2018). Indeed, Sáez et al. (2018) demonstrated that a relative humidity of $60 \%$ during storage involves the increase of Rsv level by a factor of about 68 whereas at $70 \%$ this level increases only a half. As discussed above, this could be due to the impact of drought stress. Additionally, the patent of Valagro company highlights the influence of particles size of the powdered Melon de Bourgogne grape canes with a better extraction efficiency for a $4 \mathrm{~mm}$ particles size than for $1 \mathrm{~mm}$ and 8 $\mathrm{mm}$ with respectively $915 \mathrm{mg}(\mathrm{Rsv}) \cdot \mathrm{kg}^{-1}$ and $8170 \mathrm{mg}(\mathrm{Vf}) \cdot \mathrm{kg}^{-1}, 764 \mathrm{mg}_{(\mathrm{Rsv})} \cdot \mathrm{kg}^{-1}$ and 5482 $\mathrm{mg}(\mathrm{Vf}) \cdot \mathrm{kg}^{-1}, \quad 387 \mathrm{mg}_{(\mathrm{Rsv})} \cdot \mathrm{kg}^{-1}$ and $6440 \mathrm{mg}(\mathrm{Vf}) \cdot \mathrm{kg}^{-1}$ (Soum et al., 2015). Recently, Zwingelstein et al. (2019) also demonstrated that Rsv is more efficiently extracted for $<$ $4 \mathrm{~mm}$ than for $<0.2 \mathrm{~mm}$ particles of Jacquère and Mondeuse grape canes while $\mathrm{Vf}$ extraction is drastically reduced for rougher material. The results of Jesus et al. (2019) highlight that particles size could probably influence the conclusions that are given on the impact of an extraction parameter. Indeed, personal analysis of the data that the authors obtained thanks to experimental design suggests that temperature increase (ranging from $46-114{ }^{\circ} \mathrm{C}$ for CSLE and $60-120^{\circ} \mathrm{C}$ for MAE) has a really weak effect on Rsv extraction from Loureiro grape canes powdered at $8 \mathrm{~mm}$ unlike what was discussed in the section 2.3. Rajha et al. (2015a) also demonstrated that the grape canes degradation with electrical pretreatments improves the extraction of Rsv and polyphenols. Furthermore, a toasting step after grinding of Airén and Moscatel grape canes led to Rsv concentration from 6 times to 14 times higher (depending on the vine variety) compared to non-toasted samples when conditions are optimized (Sánchez- 
Gómez et al., 2016). In the same way, grape pomace submitted to drying at $60{ }^{\circ} \mathrm{C}$ from 90 min to 180 min also presents a decrease in Rsv extraction but the same trend is not observed at $70{ }^{\circ} \mathrm{C}$ and $80{ }^{\circ} \mathrm{C}$ where a longer duration favors the stilbene recovery (Planinić et al., 2015).

This list of parameters is not exhaustive but allows to highlight the importance of being cautious with the comparison of results when working with plant material.

\subsection{Work-up parameters and analyses}

The way to treat the crude extracts before analyses has also an impact on the quantification of the molecules of interest. The discovery of Morel-Salmi et al. (2014) taken in Caudalie's patent revealed that polyvinylidene difluoride (PVDF) filter (used before analyses) adsorbs specifically Vf that is then absent of the extracts analyzed and then distorts the results (Vercauteren and Salmi, 2012). It seems that Vf solubilized in methanol/water 10:90 (v/v) is also retained at $24 \%$ on polytetrafluoroethyle (PTFE) filters and at $96 \%$ on cellulose acetate and polyethylene sulfone (PES) filters (Courtois et al., 2019). Moreover, trans-e-viniferin standard being expensive, the ways for its quantification are numerous. Some authors expressed Vf concentrations in term of Rsv equivalents, others used Vf purified from vines and others used commercial standards (Karacabey et al., 2012; Vergara et al., 2012; Pawlus et al., 2013; Tř́íska et al., 2017). Lambert et al. (2013) and Gorena et al. (2014) also warned about this point in their work. Finally, as seen in Table 1, authors do not always precise the amount of water 
contained in the plant material (depending on the storage duration for example) and that could obviously alter the results.

\section{Conclusion and perspectives}

The present review attempted to discuss the extraction methods existing for transresveratrol and trans- $\varepsilon$-viniferin recovery from grape canes. The conventional, ultrasound-assisted, microwave-assisted and pressurized solvent extractions are the most frequently studied. The emerging methods are not necessarily more efficient than the classical one but are generally less time-consuming and all of them require important amounts of solvent. The examples that are discussed also highlight an evident lack of consistent comparison to define which technic is the most appropriate for the mentioned application. Indeed, most of authors target the optimization of their process whereas the evolution of Rsv and Vf recovery under such and such imposed parameter and its interactions with the others is not clearly understood. Then, it is impossible to know if the efficiency of a method is relative to the activation method used, for example, ultrasound or microwaves irradiation, or to the impact of classical parameters such as duration, temperature, solvent-to-solid ratio, etc. Furthermore, most of extraction processes generate non-purified extracts that could still contain phytochemicals residues (Rodríguez-Cabo et al., 2018). On the other hand, biological parameters and post-pruning treatments (variety, provenance, storage duration, etc) of grape canes have also to be considered but with the interesting possibility to optimize some parameters described above. Consequently, further investigations are required in 
this field. In addition, if trans-resveratrol and trans-e-viniferin are the predominant stilbenes in grape canes, other interesting polymerized stilbenes are present in the plant material as hopeaphenol, ampelopsins and vitisins (Schnee et al., 2013; Gabaston et al., 2019). Finally, extractible compounds such as stilbenes represent only $3.1 \%$ of the grape canes total mass that means that more than $95 \%$ of the initial material remain unvalued (Dávila et al., 2017). The remained woody material could be used in a second part for the production of nutrients for ruminants or biosurfactants to cite a few examples (Molina-Alcaide et al., 2008; Cortés-Camargo et al. 2016).

\section{Acknowledgements}

The authors gratefully acknowledge the Agence de l'Environnement et de Maitrîse de l'Energie (ADEME) and the Conseil Savoie Mont Blanc (CSMB) for the awarding of the $\mathrm{PhD}$ scholarship to Marion Zwingelstein. They also thank the Universite Savoie Mont Blanc and its foundation for their final supports.

\section{References}

Abosede, I.A., Peter, O.A., Adunola, A.-A.T., 2017. Biomass Valorization: Agricultural Waste in Environmental Protection, Phytomedicine and Biofuel Production. In: Biomass Volume Estimation and Valorization for Energy. Edited by Tumuluru J. S.

Acuña-Avila, P.E., Vásquez-Murrieta, M.S., Franco Hernández, M.O., López-Cortéz, Ma. del S., 2016. Relationship between the elemental composition of grapeyards and bioactive compounds in the Cabernet Sauvignon grapes Vitis vinífera harvested in Mexico. Food Chem. 203, 79-85.

Alexandru, L., Binello, A., Mantegna, S., Boffa, L., Chemat, F., Cravotto, G., 2014. Efficient green extraction of polyphenols from post-harvested agro-industry vegetal sources in Piedmont. C. R. Chimie, 17, 212-217.

Andre, P., Renimel, I., 2014. Protecting and regenerating composition. EP1820492.

Angelov, G., Boyadzhiev, L., Georgieva, S., 2016. Useful Bioactive Substances from Wastes: Recovery of Trans-Resveratrol from Grapevine Stems. Open Chem. Eng. J. 10, 4-9.

Angelov, G., Boyadzhieva, S.S., Georgieva, S.S., 2014. Rosehip extraction: Process optimization and antioxidant capacity of extracts. Cent. Eur. J. Chem. 12, 502-508. 
Angelov, G., Georgieva, S., Boyadzhieva, S., Boyadzhiev, L., 2015. Optimizing the extraction of globe artichoke wastes. Comptes Rendus Académie Bulg. Sci. Sci. Mathématiques Nat. 68, 12351240.

Baur, J.A., Pearson, K.J., Price, N.L., Jamieson, H.A., Lerin, C., Kalra, A., Prabhu, V.V., Allard, J.S., Lopez-Lluch, G., Lewis, K., Pistell, P.J., Poosala, S., Becker, K.G., Boss, O., Gwinn, D., Wang, M., Ramaswamy, S., Fishbein, K.W., Spencer, R.G., Lakatta, E.G., Le Couteur, D., Shaw, R.J., Navas, P., Puigserver, P., Ingram, D.K., de Cabo, R., Sinclair, D.A., 2006. Resveratrol improves health and survival of mice on a high-calorie diet. Nature 444, 337-342.

Berk, Zeki, 2009. Food Process Engineering and Technology, Elsevier, 1st Edition. Elsevier.

Bhalerao, M.S., Kulkarni, V.M., Patwardhan, A.V., 2018. Ultrasound-assisted chemoenzymatic epoxidation of soybean oil by using lipase as biocatalyst. Ultrason. Sonochem. 40, 912-920.

Biesaga, M., Pyrzyńska, K., 2013. Stability of bioactive polyphenols from honey during different extraction methods. Food Chem. 136, 46-54.

Billard, C., Izard, J.-C., Roman, V., Kern, C., Mathiot, C., Mentz, F., Kolb, J.-P., 2002. Comparative Antiproliferative and Apoptotic Effects of Resveratrol, $\epsilon$-viniferin and Vine-shots Derived Polyphenols (Vineatrols) on Chronic B Lymphocytic Leukemia Cells and Normal Human Lymphocytes. Leuk. Lymphoma 43, 1991-2002.

Bouras, M., Chadni, M., Barba, F.J., Grimi, N., Bals, O., Vorobiev, E., 2015. Optimization of microwaveassisted extraction of polyphenols from Quercus bark. Ind. Crops Prod. 77, 590-601.

Bussemaker, M.J., Zhang, D., 2013. Effect of Ultrasound on Lignocellulosic Biomass as a Pretreatment for Biorefinery and Biofuel Applications. Ind. Eng. Chem. Res. 52, 3563-3580.

Cacace, J.E., Mazza, G., 2003. Mass transfer process during extraction of phenolic compounds from milled berries. J. Food Eng. 59, 379-389.

Camont, L., Cottart, C.-H., Rhayem, Y., Nivet-Antoine, V., Djelidi, R., Collin, F., Beaudeux, J.-L., Bonnefont-Rousselot, D., 2009. Simple spectrophotometric assessment of the trans-/cisresveratrol ratio in aqueous solutions. Anal. Chim. Acta 634, 121-128.

Capello, C., Fischer, U., Hungerbühler, K., 2007. What is a green solvent? A comprehensive framework for the environmental assessment of solvents. Green Chem. 9, 927-934.

Cavaliere, C., Foglia, P., Marini, F., Samperi, R., Antonacci, D., Laganà, A., 2010. The interactive effects of irrigation, nitrogen fertilisation rate, delayed harvest and storage on the polyphenol content in red grape (Vitis vinifera) berries: A factorial experimental design. Food Chem. 122, 1176-1184.

Cebrián, C., Sánchez-Gómez, R., Salinas, M.R., Alonso, G.L., Zalacain, A., 2017. Effect of post-pruning vine-shoots storage on the evolution of high-value compounds. Ind. Crops Prod. 109, 730-736.

Çetin, E.S., Altinöz, D., Tarçan, E., Göktürk Baydar, N., 2011. Chemical composition of grape canes. Ind. Crops Prod. 34, 994-998.

Chastang, T., 2014. Etude de la synthèse du resvératrol et de ses dérivés (viniférines) par des suspensions de cellules de vigne et optimisation de la production en bioréacteur ( $\mathrm{PhD}$ thesis). Ecole Centrale Paris.

Chatel, G., 2017. Sonochemistry: new opportunities for green chemistry. World Scientific Europe Ltd.

Chatel, G., De Oliveira Vigier, K., Jérôme, F., 2014. Sonochemistry: What Potential for Conversion of Lignocellulosic Biomass into Platform Chemicals? ChemSusChem 7, 2774-2787.

Chemat, F., Vian, M.A., Cravotto, G., 2012. Green extraction of natural products: concept and principles. Int. J. Mol. Sci. 13, 8615-8627.

Chemat, F., Rombaut, N., Sicaire, A.-G., Meullemiestre, A., Fabiano-Tixier, A.-S., Abert-Vian, M., 2017. Ultrasound assisted extraction of food and natural products. Mechanisms, techniques, combinations, protocols and applications. A review. Ultrason. Sonochem. 34, 540-560.

Chen, H., Deng, Q., Ji, X., Zhou, X., Kelly, G., Zhang, J., 2016. Glucose oxidase-assisted extraction of resveratrol from Japanese knotweed (Fallopia japonica). New J. Chem. 40, 8131-8140.

Cho, Y.-J., Hong, J.-Y., Chun, H.S., Lee, S.K., Min, H.-Y., 2006. Ultrasonication-assisted extraction of resveratrol from grapes. J. Food Eng., 77, 725-730. 
Cortés-Camargo, S., Pérez-Rodríguez, N., Oliveira, R.P. de S., Huerta, B.E.B., Domínguez, J.M., 2016 Production of biosurfactants from vine-trimming shoots using thehalotolerant strain Bacillus tequilensis ZSB10. Ind. Crops Prod., 79, 258-266

Courtois, A., Garcia, M., Krisa, S., Atgié, C., Sauvant, P., Richard, T., Faure, C., 2019. Encapsulation of $\varepsilon$-viniferin in onion-type multi-lamellar liposomes increases its solubility and its photo-stability and decreases its cytotoxicity on Caco-2 intestinal cells. Food Funct. 10, 2573-2582.

Cousin, T., Chatel, G., Kardos, N., Andrioletti, B., Draye, M., 2019. High frequency ultrasound as a tool for elucidating mechanistic elements of cis-cyclooctene epoxidation with aqueous hydrogen peroxide. Ultrason. Sonochem. 53, 120-125.

Couto, S.R., Rodríguez, R., Gallego, P.P., Sanromán, A., 2003. Biodegradation of Grape Cluster Stems and Ligninolytic Enzyme Production by Phanerochaete chrysosporium during Semi-Solid-State Cultivation. Acta Biotechnol. 23, 65-74.

Dávila, I., Gullón, P., Andrés, M.A., Labidi, J., 2017. Coproduction of lignin and glucose from vine shoots by eco-friendly strategies: Toward the development of an integrated biorefinery. Bioresour. Technol. 244, 328-337.

Del-Castillo-Alonso, M.Á., Castagna, A., Csepregi, K., Hideg, É., Jakab, G., Jansen, M.A.K., Jug, T., Llorens, L., Mátai, A., Martínez-Lüscher, J., Monforte, L., Neugart, S., Olejnickova, J., Ranieri, A., Schödl-Hummel, K., Schreiner, M., Soriano, G., Teszlák, P., Tittmann, S., Urban, O., Verdaguer, D., Zipoli, G., Martínez-Abaigar, J., Núñez-Olivera, E., 2016. Environmental Factors Correlated with the Metabolite Profile of Vitis vinifera cv. Pinot Noir Berry Skins along a European Latitudinal Gradient. J. Agric. Food Chem. 64, 8722-8734.

Delgado-Torre, M.P., Ferreiro-Vera, C., Priego-Capote, F., Pérez-Juan, P.M., Luque de Castro, M.D., 2012. Comparison of Accelerated Methods for the Extraction of Phenolic Compounds from Different Vine-Shoot Cultivars. J. Agric. Food Chem., 60, 3051-3060.

Directive 2008/98/CE of the European Parliament and of the Council on waste and repealing certain Directives. The Official Journal of European Union, p. 3-30, OJL L312/3, 2008.

Directive 2010/75/EU of the European Parliament and of the Council on industrial emissions (integrated pollution prevention and control). The Official Journal of European Union, p. 17-119, OJL L 334/17, 2010.

Draye, M., Bazureau, J.P., 2012. Ultrasound and microwaves: recent advances in organic chemistry. Research signpost.

Draye, M., Estager, J., Malacria, Max, Coddard, Jean-Philippe, Ollivier, Cyril, 2009. Organic sonochemistry, Editions T.I.

Eskilsson, C.S., Björklund, E., 2000. Analytical-scale microwave-assisted extraction. J. Chromatogr. A. 902, 227-250.

Ewald, P., Delker, U., Winterhalter, P., 2017. Quantification of stilbenoids in grapevine canes and grape cluster stems with a focus on long-term storage effects on stilbenoid concentration in grapevine canes. Food Res. Int. 100, 326-331.

Farina, A., Ferranti, C., Marra, C., 2006. An improved synthesis of resveratrol. Nat. Prod. Res. 20, 24752.

FranceAgriMer. Accessed in 2019 at https://www.franceagrimer.fr.

Francioso, A., Mastromarino, P., Masci, A., d'Erme, M., Mosca, L., 2014. Chemistry, stability and bioavailability of resveratrol. Med. Chem. 10, 237-245.

French Environment \& Energy Management Agency (ADEME). Accessed in 2019 at https://www.ademe.fr/en.

Gabaston, J., Leborgne, C., Waffo- Teguo, P., Valls, J., Pinto, A.P., Richard, T., Cluzet, S., Mérillon, J.M., 2019. Wood and roots of major grapevine cultivars and rootstocks: A comparative analysis of stilbenes by UHPLC-DAD-MS/MS and NMR. Phytochem. Anal. 30, 320-331.

Galanakis, C., 2017. Handbook of Grape Processing By-Products: Sustainable Solutions. 1st Edition. Elsevier.

Gogate, P.R., Kabadi, A.M., 2009. A review of applications of cavitation in biochemical engineering/biotechnology. Biochem. Eng. J., Invited Review Issue 2009 44, 60-72. 
Gorena, T., Saez, V., Mardones, C., Vergara, C., Winterhalter, P., von Baer, D., 2014. Influence of postpruning storage on stilbenoid levels in Vitis vinifera L. canes. Food Chem. 155, 256-263.

Guardia, M. de la, Armenta, S., 2010. Green Analytical Chemistry: Theory and Practice. In: Comprehensive Analytical Chemistry. Volume 57, 1st Edition. Elsevier.

Guerrero, R.F., Biais, B., Richard, T., Puertas, B., Waffo-Teguo, P., Merillon, J.-M., Cantos-Villar, E., 2016. Grapevine cane's waste is a source of bioactive stilbenes. Ind. Crops Prod. 94, 884-892.

Guerrero, R.F., Puertas, B., Fernández, M.I., Palma, M., Cantos-Villar, E., 2010. Induction of stilbenes in grapes by UV-C: Comparison of different subspecies of Vitis. Innov. Food Sci. Emerg. Technol. $11,231-238$.

Hashim, S.N.N.S., Schwarz, L.J., Boysen, R.I., Yang, Y., Danylec, B., Hearn, M.T.W., 2013. Rapid solid-phase extraction and analysis of resveratrol and other polyphenols in red wine. J. Chromatogr. A, Advances in Food Analysis 1313, 284-290.

Hashim, S.N.N.S., Schwarz, L.J., Danylec, B., Potdar, M.K., Boysen, R.I., Hearn, M.T.W., 2016. Selectivity mapping of the binding sites of (E)-resveratrol imprinted polymers using structurally diverse polyphenolic compounds present in Pinot noir grape skins. Talanta 161, 425-436.

Hatmi, S., Gruau, C., Trotel-Aziz, P., Villaume, S., Rabenoelina, F., Baillieul, F., Eullaffroy, P., Clément, C., Ferchichi, A., Aziz, A., 2015. Drought stress tolerance in grapevine involves activation of polyamine oxidation contributing to improved immune response and low susceptibility to Botrytis cinerea. J. Exp. Bot. 66, 775-787.

Hearn, M.T.W., Langford, S., Tuck, K.L., Harris, S., Boysen, R.I., Perchyonok, V.T., Danylec, B., Schwarz, L., Chowdhury, J., 2016. Molecularly Imprinted Polymers. US2016288090.

Houillé, B., Besseau, S., Courdavault, V., Oudin, A., Glévarec, G., Delanoue, G., Guérin, L., Simkin, A.J., Papon, N., Clastre, M., Giglioli-Guivarc'h, N., Lanoue, A., 2015a. Biosynthetic Origin of E-Resveratrol Accumulation in Grape Canes during Postharvest Storage. J. Agric. Food Chem. 63, 1631-1638.

Houillé, B., Besseau, S., Delanoue, G., Oudin, A., Papon, N., Clastre, M., Simkin, A.J., Guérin, L., Courdavault, V., Giglioli-Guivarc'h, N., Lanoue, A., 2015b. Composition and Tissue-Specific Distribution of Stilbenoids in Grape Canes Are Affected by Downy Mildew Pressure in the Vineyard. J. Agric. Food Chem. 63, 8472-8477.

International Organization of Vine and Wine. Accessed in 2019 at http://www.oiv.int/en/.

Izard, J.-C., Fourneron, J.-D., 2001. Method for extracting resveratrol and/or $\varepsilon$-viniferin. WO0103713.

Jesus, M.S., Genisheva, Z., Romaní, A., Pereira, R.N., Teixeira, J.A., Domingues, L., 2019. Bioactive compounds recovery optimization from vine pruning residues using conventional heating and microwave-assisted extraction methods. Ind. Crops Prod. 132, 99-110.

Ji, M., Li, Q., Ji, H., Lou, H., 2014. Investigation of the distribution and season regularity of resveratrol in Vitis amurensis via HPLC-DAD-MS/MS. Food Chem. 142, 61-65.

Karacabey, E., Mazza, G., 2008. Optimization of Solid-Liquid Extraction of Resveratrol and Other Phenolic Compounds from Milled Grape Canes (Vitis vinifera). J. Agric. Food Chem. 56, 63186325.

Karacabey, E., Mazza, G., Bayındırlı, L., Artık, N., 2012. Extraction of Bioactive Compounds from Milled Grape Canes (Vitis vinifera) Using a Pressurized Low-Polarity Water Extractor. Food Bioprocess Technol. 5, 359-371.

Keller, M., Steel, C.C., Creasy, G.L., 2000. Stilbene Accumulation In Grapevine Tissues: Developmental And Environmental Effects. Acta Hortic. 275-286.

Lambert, C., Richard, T., Renouf, E., Bisson, J., Waffo-Téguo, P., Bordenave, L., Ollat, N., Mérillon, J.M., Cluzet, S., 2013. Comparative Analyses of Stilbenoids in Canes of Major Vitis vinifera L. Cultivars. J. Agric. Food Chem. 61, 11392-11399.

Letellier, M., Budzinski, H., 1999. Microwave assisted extraction of organic compounds. Analusis 27, 259-270.

Li, M., Kildegaard, K.R., Chen, Y., Rodriguez, A., Borodina, I., Nielsen, J., 2015. De novo production of resveratrol from glucose or ethanol by engineered Saccharomyces cerevisiae. Metab. Eng. 32, 111. 
Liazid, A., Palma, M., Brigui, J., Barroso, C.G., 2007. Investigation on phenolic compounds stability during microwave-assisted extraction. J. Chromatogr. A 1140, 29-34.

Lindgren, A.E.G., Öberg, C.T., Hillgren, J.M., Elofsson, M., 2016. Total Synthesis of the Resveratrol Oligomers ( \pm )- Ampelopsin B and ( \pm )- $\epsilon-$ Viniferin. Eur. J. Org. Chem. 2016, 426-429.

Luche, J.-L., 1998. Synthetic Organic Sonochemistry. Springer US.

Luque-Rodríguez, J.M., Pérez-Juan, P., Luque de Castro, M.D., 2006. Extraction of Polyphenols from Vine Shoots of Vitis vinifera by Superheated Ethanol-Water Mixtures. J. Agric. Food Chem. 54, 8775-8781.

Macke, S., Jerz, G., Empl, M.T., Steinberg, P., Winterhalter, P., 2012. Activity-Guided Isolation of Resveratrol Oligomers from a Grapevine-Shoot Extract Using Countercurrent Chromatography. J. Agric. Food Chem. 60, 11919-11927.

Max, B., Salgado, J.M., Cortés, S., Domínguez, J.M., 2010. Extraction of Phenolic Acids by Alkaline Hydrolysis from the Solid Residue Obtained after Prehydrolysis of Trimming Vine Shoots. J. Agric. Food Chem. 58, 1909-1917.

Molina-Alcaide, E., Mounen, A., Martín-García, A. I., 2008, By-products from viticulture and the wine industry: potential as sources of nutrients for ruminants. J. Sci. Food Agric. 88, 597-604.

Moreira, M.M., Barroso, M.F., Porto, J.V., Ramalhosa, M.J., Švarc-Gajić, J., Estevinho, L., Morais, S., Delerue-Matos, C., 2018. Potential of Portuguese vine shoot wastes as natural resources of bioactive compounds. Sci. Total Environ. 634, 831-842.

Morel-Salmi, C., Julia, A., Vigor, C., Vercauteren, J., 2014. A Huge PVDF Adsorption Difference Between Resveratrol and $\varepsilon$-Viniferin Allows to Quantitatively Purify Them and to Assess Their Anti-Tyrosinase Property. Chromatographia, 77, 957-961.

Mustafa, A., Turner, C., 2011. Pressurized liquid extraction as a green approach in food and herbal plants extraction: A review. Anal. Chim. Acta 703, 8-18.

Pawlus, A.D., Sahli, R., Bisson, J., Rivière, C., Delaunay, J.-C., Richard, T., Gomès, E., Bordenave, L., Waffo-Téguo, P., Mérillon, J.-M., 2013. Stilbenoid Profiles of Canes from Vitis and Muscadinia Species. J. Agric. Food Chem. 61, 501-511.

Pecher, V., Andre, P., 2010. Procédé de préparation d'un extrait lipophile de vigne. FR2934160.

Piñeiro, Z., Guerrero, R.F., Fernández-Marin, M.I., Cantos-Villar, E., Palma, M., 2013. UltrasoundAssisted Extraction of Stilbenoids from Grape Stems. J. Agric. Food Chem. 61, 12549-12556.

Piñeiro, Z., Marrufo-Curtido, A., Serrano, M.J., Palma, M., 2016. Ultrasound-Assisted Extraction of Stilbenes from Grape Canes. Molecules 21, 784.

Piñeiro, Z., Marrufo-Curtido, A., Vela, C., Palma, M., 2017. Microwave-assisted extraction of stilbenes from woody vine material. Food Bioprod. Process. 103, 18-26.

Pinelo, M., Rubilar, M., Jerez, M., Sineiro, J., Núñez, M.J., 2005. Effect of Solvent, Temperature, and Solvent-to-Solid Ratio on the Total Phenolic Content and Antiradical Activity of Extracts from Different Components of Grape Pomace. J. Agric. Food Chem. 53, 2111-2117.

Planinić, M., Aliakbarian, B., Perego, P., Greganić, K., Tomas, S., Bucić-Kojić, A., 2015. Influence of Temperature and Drying Time on Extraction Yield of Phenolic Compounds from Grape Pomace Variety "Portogizac." Chem. Biochem. Eng. Q. 29, 343-350.

Rajha, H.N., Boussetta, N., Louka, N., Maroun, R.G., Vorobiev, E., 2015a. Effect of alternative physical pretreatments (pulsed electric field, high voltage electrical discharges and ultrasound) on the dead-end ultrafiltration of vine-shoot extracts. Sep. Purif. Technol. 146, 243-251.

Rajha, H.N., Boussetta, N., Louka, N., Maroun, R.G., Vorobiev, E., 2014. A comparative study of physical pretreatments for the extraction of polyphenols and proteins from vine shoots. Food Res. Int., Recovery and Utilization of Valuable Compounds from Food Processing By-products 65, 462-468.

Rajha, H.N., Chacar, S., Afif, C., Vorobiev, E., Louka, N., Maroun, R.G., 2015b. $\beta$-Cyclodextrin-Assisted Extraction of Polyphenols from Vine Shoot Cultivars. J. Agric. Food Chem. 63, 3387-3393.

Raposo, R., Ruiz-Moreno, M.J., Garde-Cerdán, T., Puertas, B., Moreno-Rojas, J.M., Gonzalo-Diago, A., Guerrero, R., Ortíz, V., Cantos-Villar, E., 2016. Grapevine-shoot stilbene extract as a preservative in red wine. Food Chem. 197, 1102-1111. 
Rayne, S., Karacabey, E., Mazza, G., 2008. Grape cane waste as a source of trans-resveratrol and transviniferin: High-value phytochemicals with medicinal and anti-phytopathogenic applications. Ind. Crops Prod. 27, 335-340.

Rivière, C., Pawlus, A.D., Mérillon, J.-M., 2012. Natural stilbenoids: distribution in the plant kingdom and chemotaxonomic interest in Vitaceae. Nat. Prod. Rep. 29, 1317-1333.

Robinson, K., Mock, C., Liang, D., 2015. Pre-formulation studies of resveratrol. Drug Dev. Ind. Pharm. 41, 1464-1469.

Rodríguez-Cabo, T., Rodríguez, I., Ramil, M., Cela, R., 2018. Assessment of alcoholic distillates for the extraction of bioactive polyphenols from grapevine canes. Ind. Crops Prod. 111, 99-106.

Romain, C., Gaillet, S., Carillon, J., Vidé, J., Ramos, J., Izard, J.-C., Cristol, J.-P., Rouanet, J.-M., 2012. Vineatrol and Cardiovascular Disease: Beneficial Effects of a Vine-Shoot Phenolic Extract in a Hamster Atherosclerosis Model. J. Agric. Food Chem. 60, 11029-11036.

Rombaut, N., Tixier, A.-S., Bily, A., Chemat, F., 2014. Green extraction processes of natural products as tools for biorefinery. Biofuels Bioprod. Biorefining 8, 530-544.

Romero-Pérez, A.I., Lamuela-Raventós, R.M., Andrés-Lacueva, C., de La Torre-Boronat, M.C., 2001. Method for the quantitative extraction of resveratrol and piceid isomers in grape berry skins. Effect of powdery mildew on the stilbene content. J. Agric. Food Chem. 49, 210-215.

Roubelakis-Angelakis, K.A., 2001. Molecular Biology \& Biotechnology of the Grapevine. Springer Science \& Business Media.

Rusjan, D., Mikulic- Petkovsek, M., 2015. Phenolic responses in 1- year- old canes of Vitis vinifera cv. Chardonnay induced by grapevine yellows (Bois noir). Aust. J. Grape Wine Res. 21, 123-134.

Sáez, V., Gayoso, C., Riquelme, S., Pérez, J., Vergara, C., Mardones, C., von Baer, D., 2018. C18 coreshell column with in-series absorbance and fluorescence detection for simultaneous monitoring of changes in stilbenoid and proanthocyanidin concentrations during grape cane storage. J. Chromatogr. B 1074-1075, 70-78.

Sánchez-Gómez, R., Zalacain, A., Alonso, G.L., Salinas, M.R., 2016. Effect of toasting on non-volatile and volatile vine-shoots low molecular weight phenolic compounds. Food Chem. 204, 499-505.

Sánchez-Gómez, R., Zalacain, A., Alonso, G.L., Salinas, M.R., 2014. Vine-Shoot Waste Aqueous Extracts for Re-use in Agriculture Obtained by Different Extraction Techniques: Phenolic, Volatile, and Mineral Compounds. J. Agric. Food Chem. 62, 10861-10872.

Schnee, S., Queiroz, E.F., Voinesco, F., Marcourt, L., Dubuis, P.-H., Wolfender, J.-L., Gindro, K., 2013. Vitis vinifera Canes, a New Source of Antifungal Compounds against Plasmopara viticola, Erysiphe necator, and Botrytis cinerea. J. Agric. Food Chem. 61, 5459-5467.

Schwarz, L.J., Danylec, B., Harris, S.J., Boysen, R.I., Hearn, M.T.W., 2011a. Preparation of molecularly imprinted polymers for the selective recognition of the bioactive polyphenol, (E)-resveratrol. J. Chromatogr. A 1218, 2189-2195.

Schwarz, L.J., Danylec, B., Yang, Y., Harris, S.J., Boysen, R.I., Hearn, M.T.W., 2011b. Enrichment of (E)-Resveratrol from Peanut Byproduct with Molecularly Imprinted Polymers. J. Agric. Food Chem. 59, 3539-3543.

Schwarz, L.J., Potdar, M.K., Danylec, B., Boysen, R.I., Hearn, M.T.W., 2015. Microwave-assisted synthesis of resveratrol imprinted polymers with enhanced selectivity. Anal. Methods 7, 150154.

Shirsath, S.R., Sonawane, S.H., Gogate, P.R., 2012. Intensification of extraction of natural products using ultrasonic irradiations-A review of current status. Chem. Eng. Process. Process Intensif. 53, $10-23$.

Silva, C.G., Monteiro, J., Marques, R.R.N., Silva, A.M.T., Martínez, C., Canle, M., Faria, J.L., 2013. Photochemical and photocatalytic degradation of trans-resveratrol. Photochem. Photobiol. Sci. Off. J. Eur. Photochem. Assoc. Eur. Soc. Photobiol. 12, 638-644.

Singh, C.K., Liu, X., Ahmad, N., 2015. Resveratrol, in its natural combination in whole grape, for health promotion and disease management. Ann. N. Y. Acad. Sci. 1348, 150-160.

Soum, S., Piccirilli, A., Bataille, F., 2015. Method for Obtaining Polyphenols from a Vegetable Raw Material Containing Same. FR2998296. 
Soural, I., Vrchotová, N., Tř́íska, J., Balík, J., Horník, Š., Cuřínová, P., Sýkora, J., 2015. Various Extraction Methods for Obtaining Stilbenes from Grape Cane of Vitis vinifera L. Molecules 20, 6093-6112.

Spargo, P., 2004. Microwaves in Organic Synthesis. Edited by Andre Loupy.

Sutkar, V.S., Gogate, P.R., 2009. Design aspects of sonochemical reactors: Techniques for understanding cavitational activity distribution and effect of operating parameters. Chem. Eng. J. 155, 26-36.

Tisserant, L.-P., Aziz, A., Jullian, N., Jeandet, P., Clément, C., Courot, E., Boitel-Conti, M., 2016. Enhanced Stilbene Production and Excretion in Vitis vinifera cv Pinot Noir Hairy Root Cultures. Molecules 21, 1703.

Trela, B.C., Waterhouse, A.L., 1996. Resveratrol: Isomeric Molar Absorptivities and Stability. J. Agric. Food Chem. 44, 1253-1257.

Tř́ska, J., Vrchotová, N., Balík, J., Soural, I., Sotoláŕ, R., 2017. Variability in the Content of TransResveratrol, Trans- $\varepsilon$-Viniferin and R2-Viniferin in Grape Cane of Seven Vitis vinifera L. Varieties during a Three-Year Study. Molecules 22, 928.

Tungmunnithum, D., Garros, L., Drouet, S., Renouard, S., Lainé, E., Hano, C., 2019. Green Ultrasound Assisted Extraction of trans Rosmarinic Acid from Plectranthus scutellarioides (L.) R.Br. Leaves. Plants, 8, 50.

Vercauteren, J., Salmi, C., 2012. Method for obtaining $\varepsilon$-viniferin and/or resveratrol and corresponding products. WO2012156917.

Vergara, C., von Baer, D., Mardones, C., Wilkens, A., Wernekinck, K., Damm, A., Macke, S., Gorena, T., Winterhalter, P., 2012. Stilbene Levels in Grape Cane of Different Cultivars in Southern Chile: Determination by HPLC-DAD-MS/MS Method. J. Agric. Food Chem. 60, 929-933.

Wang, L., Weller, C.L., 2006. Recent advances in extraction of nutraceuticals from plants. Trends Food Sci. Technol. 17, 300-312.

Willenberg, I., Brauer, W., Empl, M.T., Schebb, N.H., 2012. Development of a Rapid LC-UV Method for the Investigation of Chemical and Metabolic Stability of Resveratrol Oligomers. J. Agric. Food Chem. 60, 7844-7850.

Zachová, Z., Tř́ska, J., Vrchotová, N., Balík, J., Sajfrtová, M., Sovová, H., 2018. Combining highpressure methods for extraction of stilbenes from grape cane. J. Supercrit. Fluids 142, 38-44.

Zhou, L., Jiang, B., Zhang, T., Li, S., 2019. Ultrasound-assisted aqueous two-phase extraction of resveratrol from the enzymatic hydrolysates of Polygonum cuspidatum. Food Biosci. 31, 100442

Zuin, V.G., Ramin, L.Z., 2018. Green and Sustainable Separation of Natural Products from AgroIndustrial Waste: Challenges, Potentialities, and Perspectives on Emerging Approaches. Top. Curr. Chem. 376, 3.

Zupančič, Š., Lavrič, Z., Kristl, J., 2015. Stability and solubility of trans-resveratrol are strongly influenced by $\mathrm{pH}$ and temperature. Eur. J. Pharm. Biopharm. Off. J. Arbeitsgemeinschaft Pharm. Verfahrenstechnik EV 93, 196-204.

Zwingelstein, M., Draye, M., Besombes, J.-L., Piot, C., Chatel, G., 2019. Trans-resveratrol and trans- $\varepsilon-$ viniferin in grape canes and stocks originating from Savoie Mont Blanc vineyard region: preextraction parameters for improved recovery. ACS Sustain. Chem. Eng. 7, 8310-8316. 